Board of Governors of the Federal Reserve System

International Finance Discussion Papers

Number 564

September 1996

\title{
THE USE OF THE PARALLEL MARKET RATE AS A GUIDE TO SETTING THE OFFICIAL EXCHANGE RATE
}

Nita Ghei and Steven B. Kamin

NOTE: International Finance Discussion Papers are preliminary materials circulated to stimulate discussion and critical comment. References in publications to International Finance Discussion Papers (other than an acknowledgment that the writer has had access to unpublished material) should be cleared with the author or authors. 


\begin{abstract}
This paper addresses the merits of using the parallel exchange rate as a guide to setting the official exchange rate. Ideally, policymakers would set the exchange rate at the level that would balance trade and sustainable capital flows--that level is referred to as the equilibrium exchange rate. In practice, it is difficult to identify the equilibrium exchange rate, particularly in countries that have experienced macroeconomic volatility and/or structural change. In this context, where parallel markets for foreign exchange exist, it is natural to consider the parallel rate as a proxy for the equilibrium exchange rate, since it is set directly by the market. The paper develops an analytic model to explore the relationship between the parallel exchange rate and the equilibrium rate. It is determined that only under a fairly narrow set of circumstances will the parallel rate be set at a level close to the equilibrium exchange rate. The paper then compares the evolution of official and parallel exchange rates over time, in a large sample of different countries, to provide a feel for the applicability of the previously-derived theoretical results.
\end{abstract}


The Use of the Parallel Market Rate as a Guide to Setting the Official Exchange Rate

Nita Ghei and Steven B. Kamin ${ }^{1}$

\section{Introduction}

Determining the appropriate level at which to set the exchange rate is a challenging problem for any country pursuing a managed or fixed exchange-rate policy. Ideally, a country would set its exchange rate at the real equilibrium rate, that is, the rate consistent with internal and external balance (the latter referring to balance between trade and sustainable capital-account flows). Even in relatively stable and mature industrial economies, however, the real equilibrium level of the exchange rate is usually difficult to identify. In developing countries subject to macroeconomic instability and/or structural change, this identification is even more difficult. The determination of the equilibrium real exchange rate is especiaily uncertain if the economy is in the midst of trade liberalization and other reforms that promise to change previously existing relations between trade performance and the exchange rate.

In a context where a paralle! market for foreign exchange exists, it may appear natural to consider the parallel exchange rate as a proxy for the equilibrium real exchange rate. The parallel exchange rate usually has the benefit of being determined in a free market, and hence is not obviously contaminated by the distortionary effects of government policy. Multiple exchange rate arrangements, formal and informal, legal and illegal, were the norm for developing countries until very recently. Even though an increasing number of countries have unified their exchange rates, often as part of a larger liberalization effort, parallel foreign exchange markets have

${ }^{i}$ The authors are Correspondent, The Economic Times and Senior Economist, Division of International Finance, Board of Governors of the Federal Reserve System respectively. We are grateful to Lawrence Hinkle, Peter Montiel and Steve O'Connell for helpful comments and suggestions. This paper was prepared as a chapter in an edited volume, Lawrence Hinkie and Peter Montiel, eds, Exchange Rate Managentent in Low Income Countries: Methodologies for Empirical Analysis, under preparation by the World Bank. The views expressed in this paper are ours and do not necessarily reflect those held by the Board of Governors, the World Bank, The Economic Times or other members of their staffs. We are responsible for any and all errors. 
Board of Governors of the Federal Reserve System

International Finance Discussion Papers

Number 564

September 1996

\section{THE USE OF THE PARALLEL MARKET RATE AS A GUIDE TO} SETTING THE OFFICIAL EXCHANGE RATE

Nita Ghei and Steven B. Kamin

NOTE: International Finance Discussion Papers are preliminary materials circulated to stimulate discussion and critical comment. References in publications to International Finance Discussion Papers (other than an acknowledgment that the writer has had access to unpublished material) should be cleared with the author or authors. 


\begin{abstract}
This paper addresses the merits of using the parallel exchange rate as a guide to setting the official exchange rate. Ideally, policymakers would set the exchange rate at the level that would balance trade and sustainable capital flows--that level is referred to as the equilibrium exchange rate. In practice, it is difficult to identify the equilibrium exchange rate, particularly in countries that have experienced macroeconomic volatility and/or structural change. In this context, where parallel markets for foreign exchange exist, it is natural to consider the parallel rate as a proxy for the equilibrium exchange rate, since it is set directly by the market. The paper develops an analytic model to explore the relationship between the parallel exchange rate and the equilibrium rate. It is determined that only under a fairly narrow set of circumstances will the parallel rate be set at a level close to the equilibrium exchange rate. The paper then compares the evolution of official and parallel exchange rates over time, in a large sample of different countries, to provide a feel for the applicability of the previously-derived theoretical results.
\end{abstract}


The Use of the Parallel Market Rate as a Guide to Setting the Official Exchange Rate

Nita Ghei and Steven B. Kamin ${ }^{1}$

\section{Introduction}

Determining the appropriate level at which to set the exchange rate is a challenging problem for any country pursuing a managed or fixed exchange-rate policy. Ideally, a country would set its exchange rate at the real equilibrium rate, that is, the rate consistent with internal and external balance (the latter referring to balance between trade and sustainable capital-account flows). Even in relatively stable and mature industrial economies, however, the real equilibrium level of the exchange rate is usually difficult to identify. In developing countries subject to macroeconomic instability and/or structural change, this identification is even more difficult. The determination of the equilibrium real exchange rate is especiaily uncertain if the economy is in the midst of trade liberalization and other reforms that promise to change previously existing relations between trade performance and the exchange rate.

In a context where a paralle! market for foreign exchange exists, it may appear natural to consider the parallel exchange rate as a proxy for the equilibrium real exchange rate. The parallel exchange rate usually has the benefit of being determined in a free market, and hence is not obviously contaminated by the distortionary effects of government policy. Multiple exchange rate arrangements, formal and informal, legal and illegal, were the norm for developing countries until very recently. Even though an increasing number of countries have unified their exchange rates, often as part of a larger liberalization effort, parallel foreign exchange markets have

${ }^{i}$ The authors are Correspondent, The Economic Times and Senior Economist, Division of International Finance, Board of Governors of the Federal Reserve System respectively. We are grateful to Lawrence Hinkle, Peter Montiel and Steve O'Connell for helpful comments and suggestions. This paper was prepared as a chapter in an edited volume, Lawrence Hinkie and Peter Montiel, eds, Exchange Rate Managentent in Low Income Countries: Methodologies for Empirical Analysis, under preparation by the World Bank. The views expressed in this paper are ours and do not necessarily reflect those held by the Board of Governors, the World Bank, The Economic Times or other members of their staffs. We are responsible for any and all errors. 
not disappeared as yet. Nigeria, which has never successfully unified its exchange rate, is a prominent example in Africa; in Venezuela, which unified its exchange rate in 1989, a parallel market emerged in 1994 following the reimposition of capital controls.

Notwithstanding the appeal of a market-determined exchange rate as a guide to setting the official exchange rate, however, various factors complicate the relationship between the parallel market rate and the real equilibrium exchange rate in an economy. First, while the parallel market for foreign exchange may not itself be controlled by the government, conditions in that market are likely to be affected by government policy. Relative supplies and demands for foreign currency in the parallel market will be altered by the level of the official exchange rate, the extent to which exchange and trade controls are enforced, and the government's formula for rationing foreign exchange receipts to importers. Second, because the parallel exchange market represents an asset market as well as a trade-related market, the parallel market rate is likely to reflect expectations, political concerns, capital flight, and other factors not directly associated with the real equilibrium exchange rate. Hence, only under a relatively narrow set of circumstances will the parallel market rate serve as a useful guide to determining the equilibrium value of the official exchange rate.

In this paper, we explore the determinants of the parallel market rate in order to assess its usefulness as a guide to measuring the equilibrium value of the official real exchange rate. The plan of this paper is as follows. In Section II, parallel exchange markets are defined more specifically and various characteristics of parallel exchange markets are described. ${ }^{2}$ Section III addresses the issue of the unification of exchange markets and the appropriate target for the official exchange rate. In Section IV we review a simple theoretical model of parallel exchange markets to shed light on how parallel market rates are determined in relation to both official exchange rates and equilibrium exchange rates. Section $V$ compares the evolution of parallel and official real exchange rates over time to provide a feel for the applicability of the theoretical results presented in the previous

\footnotetext{
${ }^{2}$ For general surveys of the issues associated with parallel markets for foreign exchange, see Agenor
} (1992) and Kiguel and O'Connell (1995). 
section. Section VI concludes.

\section{Essential Characteristics of Parallel Exchange Markets}

\section{II.1 Basic Definitions}

A parallel foreign exchange market system is one in which transactions take place at more than one exchange rate and at least one of the prevailing rates is a freely floating, market-determined rate (the parallel exchange rate). (Kiguel and O'Connell, 1995) Parallel market systems represent a subset of the broader category of multiple exchange rate regimes, which refer to any regimes in which two or more exchange rates are applied to the same currency. Many developing countries have applied separate, fixed exchange rates to different types of transactions, but this practice is, in essence, equivalent to a single exchange rate coupled with different taxes or subsidies (depending on the transaction). By contrast, a parallel market for foreign exchange is distinguished by the fact that the parailei exchange rate is determined freely in the market. Usuaily, the official exchange rate in parallel market systems is pegged by the authorities at a particular fixed (or crawling) rate, although in principie the official rate could be floating as well. Additionalily, it is frequentily -although not aiways - the case that the official exchange rate applies to current account transactions, while the parallel market rate, whether legal or illegal, applies to capital account transactions.

Parallel markets for foreign exchange can emerge only when the government imposes exchange controls, that is, restrictions on the volume of certain foreign exchange transactions or on the price at which such transactions are made. Trade barriers, quantitative restrictions, or high tariffs alone are not in themselves sufficient to give rise to a parallel exchange market. While such controls may affect the demand or supply of foreign currencies, they will not drive a wedge between exchange rates for different transactions, as long as foreign exchange is freely available for all transactions at an official or market-determined exchange rate. A parallel market arises when the government limits the amount of foreign exchange that can be bought or sold for particular transactions, causing excess demand or supply to spill over into a parallel market, or authorizes that exchange rates for certain transactions be pegged and for other transactions be floating. 


\section{2 Legal and Illegal Systems}

Parallel exchange rate systems may be legal or illegal. When the parallel market for foreign exchange is legal, it is often referred to as a dual exchange rate (DER) system. In these cases, most current account transactions take place at a pegged commercial rate, and capital account transactions at a market determined financial rate. A number of countries have experimented with DER systems of varying duration. Some countries maintained official dual exchange rates for long time periods, such as Belgium (from 1957 to 1990) and the Dominican Republic (until 1993). The parallel market, in these countries, was used to insulate the rest of the economy from short term capital flows. France (1971-74) and Italy (1973-74) adopted dual rates for a short period following the collapse of the Bretton Woods system as a transitory measure. Argentina, Mexico and Venezuela adopted DER regimes in the 1980 s in the wake of balance of payments crises and huge capital outflows.

Illegal parallel market systems emerge when private agents attempt to evade restrictions on the price or quantity of foreign exchange transactions. Ilegal markets were the norm in most of Africa, and South Asia, as well in several Latin American countries, especially through the 1980s. The parallel markets were generally tolerated by the authorities, with some exceptions. For example, the threat of enforcement, and penalties was significant in Ghana prior to 1983 , but these efforts fell by the wayside later on, and the coverage of the parallel market grew, as did the parallel premium (Kiguel and O'Connell, 1995). In Sudan, trading on the parallel market was a capital offence, and enforcement was attempted between 1970 and 1990 . But even the threat of capital punishment did not totally wipe out the parallel market, though it may have been a factor in the very high premium observed in Sudan.

In principle, there is little difference, in terms of macroeconomic implications, between legal and illegal systems. In either case, free-market transactions in foreign exchange take place alongside controlled pricetransactions. This means that in either legal or illegal systems, there are incentives for transactions to spill over or "leak" from one market into the other. These leakages may tend to undermine the parallel exchange rate 
system, depending upon how rigidly exchange controls are enforced.

\section{II.3: Parallel Markets in the 1990s}

A great many countries have experimented with parallel exchange arrangements at various times. These arrangements have included formal, legal dual rates as well as illegal "black" rates. However, the incidence of such arrangements has been declining in the 1990s, as an increasing number of developing countries have sought to unify their exchange rates, often as part of a larger structural reform effort which includes liberalization of the external accounts. Even partial convertibility of the currency, for current account purposes, for example, leads to progress towards unifying the exchange rate.

Observers frequently view the incidence of restrictions on international transactions as evidence of prevalence and importance of parallel exchange markets. According to IMF reports, about one-half of the member countries impose restrictions on payments on transaction on the current account; over three-quarters do so on capital account payments (Table 1). However, the mere existence of restrictions does not necessarily imply the existence of significant paraileil markets, since these are qualitative data, with two values - yes and no, and so do not capture either the intensity of restrictions or the effectiveness of enforcement. Therefore, using the existence on payments restrictions would result in an overestimate of the prevalence of parallel markets fore foreign exchange.

Parallel markets are likely to be unimportant, and the parallel premium low, when the payments restrictions and capital controls are either minimal or not enforced. For example, South Africa imposed capital controls in 1985, following massive capital outflows, and re-introduced a dual exchange rate system at that time. But the parallel premium has remained modest - the median premium was 4.4 per cent for the period 1980-89, and declined to 2.3 per cent during the period 1990-94 (Ghei, Kiguel and O’Connell 1996) - which would be considered to a unified exchange rate regime under the definition in Section 5 below. There are several other examples of countries with extremely low premia, including Thailand, Malaysia and Indonesia, with median premia varying from -1.5 to 3.4 per cent (Ghei et al, ibid). 
Table 1

Incidence of Payments Restrictions among IMF Member Countries

\begin{tabular}{||l|c|c|}
\hline & 1980 & 1994 \\
\hline Current Account & $51.77 \%$ & $51.69 \%$ \\
\hline Capital Account & $78.01 \%$ & $77.53 \%$ \\
\hline
\end{tabular}

Source: Exchange Restrictions and Exchange Arrangements: Annual Report of the IMF, various issues.

At the present moment, parallel exchange rate arrangements are to be found in developing countries only; Belgium, which was the last developed country with dual exchange rates, moved to a unified exchange rate in 1990. Parallel exchange rates were a feature of one half of our sample of twenty-four developing countries at the end of 1994 (see Table 2) ${ }^{3}$. Parallel exchange rate arrangements were even more widespread in developing countries in the 1980s - every country in our sample had more than one exchange rate in 1985 . Our sample includes countries where significant parallel markets existed for some time, and includes most of the more important developing countries, outside eastern and central Europe and the former Soviet Union.

Parallel markets have had different degrees of longevity. Argentina Mexico and Venezuela had legal dual rates that were expected to be temporary. All three created dual rates and then unified within the period, 1980 to 1994, though a parallel market did re-emerge in Venezuela in 1994, as discussed above. Other Latin American countries moved to multiple rates or unified within the same period. In the African and Asian countries, by contrast, parallel markets were more long lived. A few of these countries unified their exchange rates in the 1990s, but major exceptions remain - mostly in Africa, including Nigeria, Kenya and Zambia.

The level of the parallel premium has decreased, on average, in the countries with parallel exchange rate arrangements. We find lower premia in 1994 relative to 1985 in many cases, for our sample. For a selected group

${ }^{3}$ The sample is drawn from a World Bank research project, "Macroeconomic Implications of Multiple Exchange Rates in Developing Countries". A volume based on the project, "Parallel Exchange Rates in Developing Countries, M.A. Kiguel, J.S. Lizondo and S.A. O'Connell, eds, is forthcoming. The data were updated to the end of 1994 for this paper. 
Table 2

Status of Parallel Market / Level of Parallel Premium (\%)

\begin{tabular}{|c|c|c|c|c|}
\hline Country & 1980 & 1985 & 1990 & 1990 \\
\hline \multicolumn{5}{|c|}{ Latin American and Turkey } \\
\hline Argentina & Unified & 30.79 & 29.93 & Unified \\
\hline Bolivia & 19.85 & 223.60 & Unified & Unified \\
\hline Brazil & 8.90 & 30.12 & 14.28 & Unified \\
\hline Chile & 6.03 & 25.39 & 16.78 & 8.67 \\
\hline Colombia & Unified & 11.42 & 9.24 & 6.12 \\
\hline Dominican Rep. & 38.00 & 7.69 & 68.01 & Unified \\
\hline Ecuador & 11.45 & 76.90 & 23.53 & 5.45 \\
\hline Mexico & Unified & 28.46 & 7.41 & Unified \\
\hline Peru & 36.25 & 29.53 & 104.80 & Unified \\
\hline Uruguay & Unified & 9.41 & 10.93 & 16.51 \\
\hline Venezuela & Unified & 104.00 & Unified & 4.73 \\
\hline Turkey & 9.98 & -7.17 & Unified & Unified \\
\hline \multicolumn{5}{|l|}{ Africa and Asia } \\
\hline Algeria & 193.25 & 375.23 & 248.81 & 253.95 \\
\hline Egypt & 7.77 & 122.90 & 89.47 & Unified \\
\hline Ethiopia & 35.02 & 127.66 & 192.75 & 113.26 \\
\hline Ghana & 485.92 & 143.48 & 9.84 & Unified \\
\hline Kenya & 9.38 & 4.51 & 3.11 & 19.78 \\
\hline Malawi & 92.27 & 49.51 & 17.51 & 14.62 \\
\hline Nigeria & 67.67 & 306.22 & 19.40 & 231.87 \\
\hline Sudan & 92.40 & 27.14 & 955.45 & 53.13 \\
\hline Tanzania & 174.00 & 271.89 & 56.36 & Unified \\
\hline Zambia & 70.27 & 65.39 & 279.56 & -6.15 \\
\hline India & 9.58 & 15.12 & 9.10 & Unified \\
\hline Pakistan & 26.26 & -0.67 & 8.72 & Unified \\
\hline \# Parallel Markets & 19 & 24 & 21 & 12 \\
\hline
\end{tabular}

Notes: Premium is defined as $\left(e^{p} / e^{0}-1\right)^{*} 100$. Exchange rate is expressed as local currency/US \$. Data are annual averages calculated using ending of quarter values.

Source: IFS and World Currency Yearbook, Currency Analysis, various issues 
of high premium countries ${ }^{4}$, Ghei, Kiguel and O'Connell (1996) find that the median premium for the period 1990 to 1994 was 49 per cent, compared with a figure of 100 per cent for the period 1980-89. Similar trends have been observed for moderate and low premium countries as well.

Overall, there are indications that developing countries are moving in the direction of unified exchange rates. The number of countries with significant parallel markets has declined, and the gap between the official and the parallel rate is steadily decreasing in most of the countries that still have parallel rates.

\section{II.4 Rationale for Parallel Market Systems}

Parallel market systems emerge for different reasons in different countries. There is one legitimate rationale for a system in which current account transactions are conducted at a pegged rate and capital account transactions are conducted at a floating rate: to insulate domestic prices and economic activity from exchange rate fluctuations deriving from transitory shocks in the financial market.

In practice, the implementation of parallel market systems in developing countries rarely has been consistent with this rationale. In certain Latin American countries, dual exchange rate systems were indeed adopted in response to strong, temporary capital outflows resulting from balance-of-payments crises in the 1980s, and this did, to a certain extent, protect their economies from excessive, transitory depreciations of the exchange rate. However, the dual markets were retained long after the financial crises had passed. Moreover, even after the crises had passed, the parallel rates continued to be more depreciated than the official rates; in a dual rate system designed to protect the economy from exchange rate variability--as opposed to a system designed to target the official rate at a level persistently more appreciated than what the market would set--the parallel rate would be expected to fluctuate both above and below the official rate.

In African countries, parallel markets were even less consistent with the best rationale for the existence

${ }^{4} \mathrm{~A}$ high premium country is where the median premium exceeds 50 per cent. The term "moderate premium" is applied to countries with median premium between 10 and 50 per cent. A median level of less than 10 per cent puts a country into the low premium category. The time period examined in $1970-1994$. 
of such systems. Frequently, exchange controls were tightened in these countries as a gradual overvaluation of the official exchange rate led to excess demand for foreign exchange at the official rate. This, in turn, led to creation of parallel markets to evade such controls, even in the absence of strong capital account pressures. Hence, exchange controls were used to prop up persistently misaligned exchange rates, not to insulate the domestic economy from transitory fluctuations.

\section{II.5 Economic Function of Parallel Markets}

We have identified two central economic functions of parallel exchange markets. When parallel rates emerged following a balance of payments crisis, as was the case in much of Latin America, the parallel market was used primarily to finance capital flows in and out of the country. There was very little rationing in the market for trade transactions, as foreign exchange supply was usually enough to satisfy demand. On average, the premium of the parallel rate relative to the official rate was quite moderate in these cases - though there were occasional spikes when the premium was very high. But these spikes reflected temporary macroeconomic crises, not a drastic and persistent misalignment of the real exchange rate.

Precisely the opposite was true in the case of most African countries. In the prototypical case, foreign exchange rationing grew more stringent over time as the official exchange rate became increasingly overvalued. Importers who lacked access to ever scarcer foreign exchange through the official channels, tumed to the parallel market to obtain foreign exchange for trade transactions. The parallel premium grew to very high levels, and stayed there, as the official rate became more and more overvalued. Ghana is the textbook example for this, when by the end of the 1980s, the official exchange rate was so overvalued that it became irrelevant for most transactions; even domestic prices and inflation reflected the parallel, not the official rate (Chibber and Shaffik, 1991).

\section{Unification of Exchange Rates to a Single Equilibrium Rate}

Observers have identified various negative consequences of exchange controls and the parallel markets that they engender. A non-exhaustive list would include, first, the fact that exchange controls allow the 
authorities to maintain a persistentily misaligned officiai exchange rate--perhaps coupled with inappropriate fiscal, monetary, and commercial policies--without losing all their intemational reserves, thereby distorting reiative prices in the economy and inhibiting the growth of exports. Second, because parallel market regimes often involve the rationing of foreign exchange at subsidized rates to those with preferential access to the authorities, exchange controls encourage the development of rent-seeking behavior among private entrepreneurs. Finally, the introduction of exchange controls, which by their nature are hard to enforce and profitable to evade, tends to promote a culture of law evasion among private entrepreneurs that may spill over into other areas such as tax compliance or adherence to other economic and financial regulations.

In response to these and other adverse effects of exchange controls, an increasing fraction of developing countries have moved to dismantle exchange controls and unify their exchange markets. Some parallel markets were abandoned either because they were no longer needed (when the crisis was over) or because they were no longer effective, that is, rampant evasion of exchange controls undermined the system. Other developing countries (including Tanzania, Ghana and India) moved to legalize their parallel markets as a transitional measure while easing restrictions on current account transactions - as a step on the path to unification of the exchange rate. In those cases, unification has been part of a larger structural reform effort aimed at liberalizing markets overall.

Because the emergence of a parallel market usually reflects the existence of an excess demand for foreign exchange at the prevailing official exchange rate (so that foreign exchange must be rationed by the authorities), successful unification of the exchange markets generaily requires that the official exchange rate be devalued sufficiently to eliminate excess demands for foreign exchange. Put another way, successfui unification requires that the real official exchange rate be set at its "real equilibrium" level.

Definitions of the "real equilibrium exchange rate" abound in the literature. Here we focus on two equilibrium concepts, the "short-run" and "long-run" equilibrium exchange rates, which are more fully described in another chapter in this volume. ${ }^{5}$ The long-run equilibrium exchange rate is that rate which equates the trade

${ }^{5}$ Peter Montiel, "The Theory of the Long-Run Equilibrium Real Exchange Rate". 
balance with sustainable net capital flows, when fiscal, monetary, and commercial policies are "normal" and sustainable, when foreign asset holdings are equal to their desired levels, and when no exchange controls are in place. The short-run equilibrium exchange rate, by contrast, is the level of the exchange rate that equates the trade balance to net capital flows--that is, equates the supply and demand for foreign exchange--given current settings of economic policy and current demands for foreign capital, regardless of whether either are at their normal levels; as in the case of the long-run equilibrium rate, the short-run equilibrium real exchange rate is defined as that which induces balance-of-payments equilibrium when no exchange controls are in place.

The short-run equilibrium real exchange rate may differ from its long-run value for innumerable reasons. For example, starting out in an economy where both the exchange rate and other government policies are at their sustainable, long-run settings, the imposition of extraordinary import barriers, by reducing the effective demand for foreign exchange in the foreign exchange market, will cause the short-run equilibrium real exchange rate to appreciate relative to its long-run level. Conversely, expectations of a future devaluation or political disruption will lead to a temporary heightened demand for foreign assets that will lead the short-run equilibrium real exchange rate to depreciate in relation to the long-run equilibrium rate.

By definition, as long as the official exchange rate is at its short-run equilibrium level, there will be no imbalance between demands and supplies for foreign exchange. Therefore parallel exchange markets, to the extent that they reflect an excess demand for foreign exchange under current economic policies, are associated with real official exchange rates that are overvalued--that is, appreciated--with respect to the short-run real equilibrium exchange rate. However, successfully sustaining a unification of the exchange market probably requires that the real official rate be set to its long-run equilibrium value, not its short-run value. Moreover, it probably requires that other elements of government policy, in addition to the exchange rate, be changed as well.

To see this, consider an example in which the authorities have imposed very high quantitative restrictions (QRs) on imports, thereby reducing the effective demand for foreign exchange and appreciating the short-run real equilibrium exchange rate relative to its long-run level. At the same time, assume that the authorities have also 
set the official exchange rate at a level that is even more appreciated than the short-run equilibrium rate, so that in response to an excess demand for foreign exchange, the authorities ration dollars and a parallel market emerges. In this example, devaluing the official exchange rate to its short-run equilibrium level would unify the exchange markets, but would leave much of the distortion associated with the QRs untouched. A fully successful unification therefore would entail dismantling the QRs and devaluing the real official exchange rate all the way to its long-run equilibrium level.

In practice, some countries might not regard it as feasible, within a short period of time, both to devalue their exchange rate to its long-run equilibrium level and to adjust inappropriate fiscal, monetary, and commercial policies as well. They may fear the inflationary and distributional consequences of a very large "maxi" devaluation, and may face strong political pressures against changing particular aspects of government policy, particularly trade barriers that benefit certain vested interests. In such a case, the authorities might attempt to implement a gradual process of unification, moving the official rate toward its long-run equilibrium value even as they adjust associated economic policies in the appropriate direction as well.

Whether the authorities intend to implement either a gradual or a rapid unification, they will need to identify the long-run equilibrium value of the real exchange rate, and, as noted in the introduction, this task will be fraught with considerable uncertainty. Under these circumstances, the prevailing parallel exchange rate appears as an obvious proxy for the equilibrium rate, and the authorities might naturally consider the parallel rate

to be an appropriate target toward which to move the official rate, either gradually or all at once. As shown in the following section, however, there are many factors that could cause the parallel rate to diverge significantly from its long-run equilibrium value, making it, in many instances, an inappropriate target for the official exchange rate.

\section{A Simple Model of Parallel Exchange Rate Determination}

This section presents a simple partial equilibrium model to illustrate how the parallel market exchange rate is determined in relation both to the official exchange rate and to the long-run equilibrium exchange rate, that 
is, the rate that would produce equilibrium in the balance of payments under normal, sustainable policy conditions. ${ }^{6}$ There is no consensus regarding the most appropriate model to use in explaining the parallel market rate, just as there is no agreement as to which model best explains the movement of floating exchange rates among industrial countries. The model illustrated below has the advantage of being relatively straightforward and intuitive, while hopefully highlighting the most important features influencing the parallel market rate.

\section{IV.1 Basic Setup}

Consider a small open economy trading in two goods, a non-domestically consumed export good and a non-domestically produced import; the world prices of both goods are fixed and set to unity. To focus on developments in the external sector, we assume it to be small relative to the domestic economy, so that the analysis describes the operation of the parallel exchange market in partial equilibrium. Therefore, the output of a non-traded good and its price are considered fixed as well. We assume for convenience that the US dollar is the only foreign currency traded.

Turning to the parameters of government policy, it is assumed that monetary and fiscal policies are at their long-run, sustainable levels, and moreover, for analytical convenience, there are no tariffs, subsidies, or other commercial policy interventions. (The role of import barriers will be examined later.) Therefore, in terms of the definitions introduced in the preceding section, the short-run real equilibrium value of the exchange rate is, at least initially, the same as its long-run value. The official exchange rate $\mathbf{E}$ (measured in terms of domestic currency per dollar) is pegged at an overvalued level relative to the equilibrium rate. Therefore, at that level of the exchange rate, the flow demand for dollars (to be elaborated below) exceeds their flow supply. Exporters are required to surrender their dollar earnings to the central bank at the official rate $\mathbf{E}$. Importers purchase dollars from the central bank, which rations dollar sales OS, based on the amount of export revenues surrendered to the central bank $\mathbf{O X}$, according to the central bank rationing function:

\footnotetext{
${ }^{8}$ The model and its exposition are based on the analysis presented in Kamin $(1993,1995)$.
} 


$$
O S=O S(O X), O S^{\prime}()>0
$$

In response to the prevailing excess demand for dollars at the official rate E, a parallel market for dollars priced at the parallel market rate $\mathrm{E}^{\mathrm{p}}$ emerges. We follow the conventional stock/flow approach to exchange rate determination in positing that in the long run, the parallel rate moves so as to equate flow demands for dollars by importers with flow supplies for dollars by exporters. That is, in the long run $\mathrm{E}^{\mathrm{p}}$ is set so as to balance the private sector's current account. In the short run, on the other hand, the parallel market rate is assumed to move exclusively to set the portfolio demand for dollars equal to the stock of dollars outstanding, so that at any given moment, the private current account may be out of balance.

\section{IV.2 The Parallel Market Rate in Long Run Current Account Equilibrium}

We now analyze the determination of the parallel market rate in private current account equilibrium. The private sector current account is defined as the difference between private dollar inflows or supplies $\mathbf{S}$ and outflows or demands D. We assume that foreigners hold no domestic assets, so that changes in the stock of dollars held by the private sector, B, occur exclusively through imbalances in the private sector's current account:

$$
d B=S-D
$$

The current account (or flow) demand for dollars is a derived demand for imported goods. Arbitrage ensures that the price of the import will be the same, whether purchased from a legal importer with access to official foreign exchange or from a smuggler using dollars purchased in the parallel market. ${ }^{7}$ In either case, the price of imports will be set equal to its marginal cost, the parallel market rate $\mathbf{E}^{\mathrm{P}}$ (since by assumption, the foreign currency price is set to unity). Therefore, the private demand for imports, as indicated in equation 3 below,

\footnotetext{
${ }^{7}$ We assume that there are no tariffs and that restrictions on smuggling are costlessly evaded. The latter assumption is relaxed below.
} 
depends (negatively) upon the domestic currency price of imports $\mathbf{E}^{\mathrm{P}}$ relative to the price of non-tradeables $\mathbf{P}^{\mathbf{a}}{ }^{8}$

$$
D=D\left(E^{p} / P^{n}\right)=D\left(e^{P}\right), \quad D^{\prime}()<0
$$

where $\mathrm{e}^{\mathrm{p}}$ is the real parallel exchange rate.

The current account (or flow) supply of dollars derives both from under-invoiced dollar earnings--that is, export receipts not turned over to the central bank--and from official dollar sales to importers OS. Note that while holders of import licenses have an incentive to over-invoice, this does not add to the total supply of dollars to the private sector, which is fixed by the central bank's rationing function (equation 1). Let $\mathbf{X}$ represent the quantity of total exports and total dollar revenues as well (since the world price is set to unity), while $\phi$ represents the share of total export proceeds diverted to the parallel market. Then

$$
S=\phi X+O S(O X)=\phi X+O S((1-\phi) X)
$$

Exporters maximize domestic currency profits subject to rising marginal costs of production--which we assume to be related to the price of non-traded goods--as well as rising costs associated with the under-invoicing share $\phi$. We can derive the supply curve for total exports as a function of the weighted average of the real (nontradeables price deflated) official (e) and parallel market exchange rates $\left(\mathrm{e}^{p}\right):^{9}$

$$
X=X\left(\phi e^{p}+(1-\phi) e\right), \quad X^{\prime}()>0
$$

The under invoicing share $\phi$ can be shown to positively depend upon the real parallel market premium:

$$
\phi=\phi\left(e^{p}-e\right), \quad \phi^{\prime}()>0
$$

${ }^{8}$ In principle, import demand is a function of income as well. Since, in this partial equilibrium model, income is considered to be fixed, we do not include it explicitly in the demand function.

${ }^{9}$ See Kamin (1993) for details. 
For a given value of the real official rate $e$, a unique real parallel market rate $\mathrm{e}^{\mathrm{p}}$ will equate dollar demands and supplies in equilibrium:

$$
D\left(e^{P}\right)=\phi X+O S(O X)
$$

This equation can be further simplified if we posit that, on average and over a long enough time period, the central bank will have roughly stable international reserves. Therefore, we can assume that over a long time period, the central bank will resell all surrendered export receipts $O X=(1-\phi) X$ to licensed importers, after it extracts any foreign exchange needs of the government (assumed to be invariant to the exchange rate) $D^{\text {s:10 }}$

$$
O S(O X)=O X-D^{:}=(1-\phi) X-D^{8}
$$

Therefore, equation 7 can be rewritten as

$$
D\left(e^{p}\right)=\phi X+(1-\phi) X-D^{8}=X-D^{8}=X\left(\phi e^{p}+(1-\phi) e\right)-D^{8}
$$

Figure 1 below depicts various different equilibria in the parallel exchange market, depending upon the value of e set by the authorities. The DD curve depicts equation 3, the private demand for foreign exchange as a function of the real parallel rate $e^{p}$. The SS curve depicts the supply of foreign exchange to the market as a function of $e^{p}$; its location also is a function of $e$, since both $e^{p}$ and $e$ affect the total quantity of exports supplied. $e^{*}$ is the long-run equilibrium real exchange rate, that is, the level of the real exchange rate that would clear the market - set total demands for foreign exchange equal to total supplies - in a unified foreign exchange market. Note that when the official exchange rate is set equal to $\mathrm{e}^{*}$, the parallel rate also must equal $\mathrm{e}^{*} .^{11}$ In other words,

${ }^{10}$ This is consistent with assumptions in Sheik (1976) and Nowak (1984).

${ }^{11}$ We know this because if $D\left(e^{*}\right)=X\left(e^{*}\right)-D^{8}$

in a unified exchange market, and if in a parallel market system, $D\left(e^{p}\right)=X\left(\phi e^{p}+(1-\phi) e^{*}\right)-D^{8}$, 


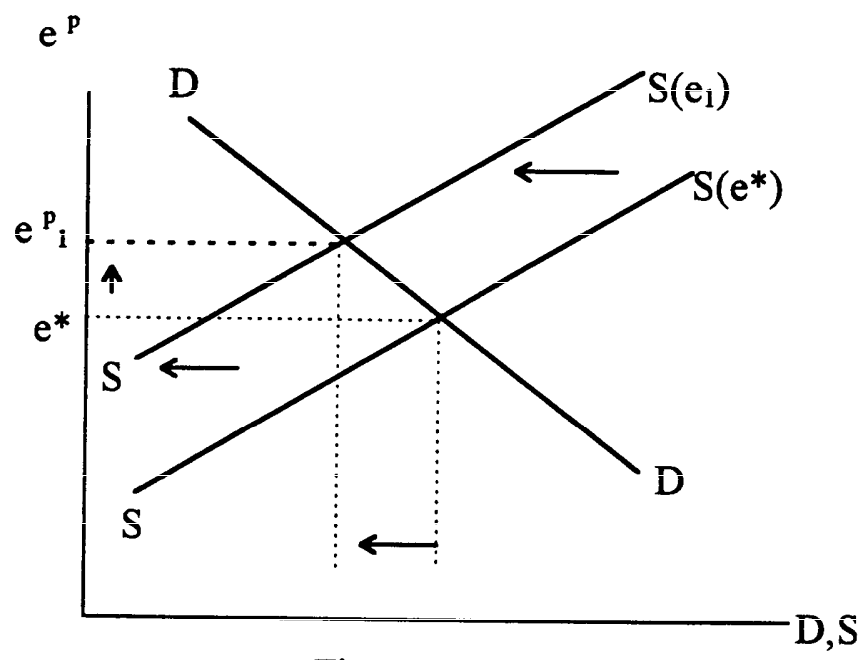

Figure 1 
when the official exchange rate is set at its equilibrium value, there is no current-account motive for the emergence of a parailei foreign exchange market, since there is no excess demand for foreign exchange at the official rate.

We now consider the effects on the real parallel rate of a real appreciation of the official rate. Assume that the authorities allow the official rate $\mathrm{e}$ to appreciate to an overvalued level $\mathrm{e}_{1}<\mathrm{e}^{*}$. Because this lowers the profitability of exports, the supply curve SS shifts inwards, creating an excess demand for foreign exchange at that rate. This puts upward pressure on the foreign exchange value of the dollar in the (now emergent) parallel market, causing the parallel exchange rate to depreciate from $\mathrm{e}^{*}$ to $\mathrm{e}_{1}^{\mathrm{p}}{ }^{12}$

Hence, in cases where the emergence of the parallel market reflects the overvaluation of the official commercial exchange rate, the parallel market rate, on average, is likely not only to be more depreciated than the commercial rate, but it probably is more depreciated than the long-run equilibrium exchange rate as well. Various factors are likely to determine the extent to which the parallel rate is more depreciated that the equilibrium exchange rate. As Figure 1 makes obvious, the more overvalued the official exchange rate, and so the greater the extent to which the SS curve shifts inwards, the greater will be the gap between the parallel rate and the equilibrium rate. It also is straightforward to show that the gap will be greater, the more elastic are exports and the less elastic are imports with respect to the exchange rate.

The extent to which export surrender requirements are enforced plays a key role in determining the value of the parallel exchange rate, as well. Recall that total exports are a function of a weighted average of the real official and parallel exchange rates. If foreign exchange regulations are tightly enforced, export under invoicing will be limited, reducing the under invoicing ratio $\phi$ and thereby increasing the weight placed on the official exchange rate. In this case, the overvaluation of the official exchange rate depresses total exports significantly, reducing the suppiy of foreign exchange to the parallel market, and depreciating the real parallel market exchange

then it is obvious by inspection that the second equation is satisfied for $e^{p}=e^{*}$.

${ }^{12}$ This result is consistent with that found by Nowak (1984). 
rate substantially relative to the equilibrium rate.

Conversely, if foreign exchange regulations are poorly enforced and widely evaded, the under invoicing ratio will be higher, the weighted average exchange rate will be more favorable for exporters, and total exports will not be as severely depressed. This will lead to less pressure on the parallel market exchange rate and a smaller gap relative to the equilibrium rate. At an extreme, as to some extent occurred in some African countries, the official exchange rate becomes so widely evaded as to become irrelevant to most economic decisions. In this context, most trade is routed through the underground economy, and the parallel exchange rate may become a reasonably accurate guide to the long-run equilibrium rate.

Finally, the value of the parallel exchange rate in long-run equilibrium is likely to be influenced by the extent to which barriers to imports (above and beyond merely rationing official sales of foreign exchange through exchange controls) are enforced. The above analysis assumes that once importers acquire foreign exchange, whether officially or from the black market, they may use that financing to freely import goods. However, if the authorities impose high import barriers and they are well-enforced, so that smuggling is costly, this will act to reduce the demand for foreign exchange in the black market--that is, the DD curve shown in Figure 1 would shift inwards and to the left. This reduced demand, in turn, would cause the short-run real equilibrium exchange rate to appreciate relative to its long-run value, since the long-run equilibrium value of the real exchange rate is predicated on the absence of extraordinary commercial policies of this sort. The imposition of the barriers also would lead the real parallel exchange rate to appreciate relative to the case where import barriers are not enforced. For sufficiently tight controls on imports, the real parallel rate could also be more appreciated than the long-run equilibrium real rate.

\section{IV.3 The Parallel Market Rate in Short-Run Portfolio Equilibrium}

The results described above are likely, at best, to hold on average over relatively long periods of time. In the very short term, the stock of dollars held by the private sector is considered to be fixed, since it takes time to accumulate or decumulate dollars through current account imbalances; during this short run, the parallel market 
rate conventionally is modeled as being determined by the portfolio-based demand for dollars. This portfolio demand depends upon the relative expected rates of return to holding dollars and domestic assets, which are influenced by anticipated inflation, other aspects of macroeconomic performance, and political events as well. The volatility of such expectations largely explains the high volatility exhibited by most freely floating exchange rates, including parallel market exchange rates.

For a simple theoretical exposition, assume that private sector agents hold two assets in their portfolio, dollars and domestic currency. Following Dornbusch et. al. (1983), the desired ratio of the domestic currency value of private sector dollar holdings to the nominal domestic money supply (M) is modeled as a function of the expected rate of depreciation of the black market rate (the $\wedge^{\wedge}$ denotes percentage change):

$$
\frac{E^{P} B}{M}=\Phi\left(\hat{E}^{P}\right), \quad \Phi^{\prime}()>0
$$

or, dividing through by non-traded goods prices,

$$
\frac{e^{p} B}{m}=\Phi\left(\hat{E}^{p}\right), \quad m=\frac{M}{P^{n}}
$$

The notation for the rate of depreciation, $\hat{\mathbf{E}}^{\mathrm{p}}$, omits an expectational term to reflect the assumption of perfect foresight. The portfolio demand for dollars (when the parallel market rate is stable) traces out a downward sloping curve in ( $\left.e^{p}, \mathbf{B}\right)$ space as shown in Figure 2. Given that $\mathbf{B}$ is considered fixed at any one moment, the level of $\mathbf{B}$ determines the level of $\mathrm{e}^{p}$ at that moment.

In the long run, the parallel market rate and the private stock of dollar holdings are determined by the requirements of both portfolio and current account equilibrium. In addition to the portfolio equilibrium condition described above, Figure 2 depicts the locus of points for which the private current account is in equilibrium, so that the stock of dollars $B$ held by the private sector is unchanging. This curve, denoted $\mathbf{d B}=0$, is vertical, since 


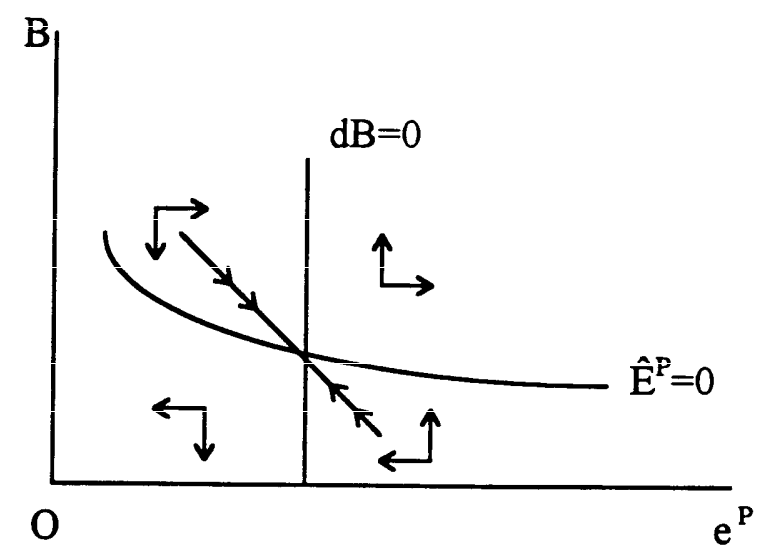

Figure 2 
for any given official exchange raie, a single value of the parailei market rate $\mathrm{e}^{\mathrm{p}}$ clears the private current account. ${ }^{13}$ The point where the two curves cross--the steady-state equilibrium--is the only point where both the current account is in equilibrium and the stock of dollars held by the private sector equals its portfolio demand. Finally, the vertical and horizontal arrows represent the direction of movement of $\mathbf{B}$ and $\mathrm{e}^{\mathrm{p}}$ outside of equilibrium, while the diagonal line--the "stable saddle path"--indicates the path by which $\mathbf{B}$ and $\mathrm{e}^{\mathrm{p}}$ converge toward equilibrium, should they start out outside of equilibrium.

We now consider the effects on the parallel market rate of a rise in inflation--say, from 0 to 20 percent-leading to higher rates of nominal depreciation of the official and parallel exchange rates. This is an important example, since many countries that imposed exchange controls experienced increases in inflation and other measures of macroeconomic volatility at about the same time, particularly in Latin America (and Turkey).

As shown in Figure 3, the increased expected level of inflation-and hence of nominal depreciation of the parallel market rate--leads agents to desire to hold a higher ratio of dollars to domestic currency, causing the portfolio balance curve to shift upwards. Equilibrium dollar holdings shift from $\mathbf{B}_{\mathbf{0}}$ to $\mathbf{B}_{1}$, while the equilibrium real parallel market rate remains unchanged. However, in order to accumulate additional dollars, the private current account must shift into surplus temporarily, which in turn requires a temporary depreciation of the real parallel exchange rate. Hence, at the moment of increased inflation expectations, the parallel market rate jumps from initial equilibrium at (1) to the new stable saddle path at (2). After this, the accumulation of dollars through the current account surplus reverses the depreciation of the real parallel market rate until the system returns to equilibrium at (3).

In the example depicied above, the reai parailel exchange rate becomes, for a time, more depreciated than its own equilibrium level (conditional on the value of the real official rate). (As a result of these temporary capital

${ }^{13}$ For simplicity, this analysis abstracts from the interest payments associated with net asset holdings, as well as from the wealth effects of asset holdings on import demand. In the presence of interest payments or wealth effects, the $\mathrm{dB}=0$ curve would not be vertical, since the value of the parallel market exchange rate that cleared the private current account would depend upon the stock of dollar holdings B. 


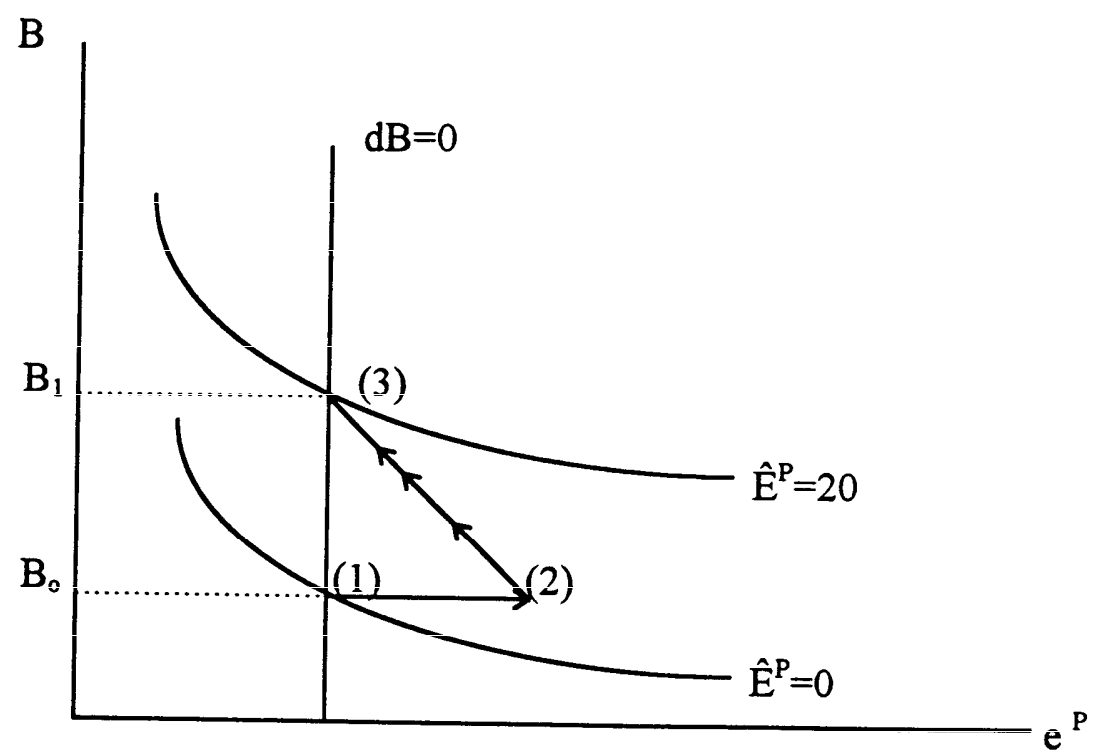

Figure 3 
outflows, the short-run equilibrium exchange rate in a unified market also would depreciate relative to its long-run equilibrium level.) Since the equilibrium level of the parallel exchange rate is likely, as shown in Section III.2, to be more depreciated than the long-run equilibrium rate in a unified exchange market, this means that the parallel rate during periods of macroeconomic volatility and capital outflows will be more depreciated still. Hence, during periods of macroeconomic volatility and heavy capital outflows, the parallel rate is likely to be a particularly biased guide to setting the appropriate level of the official exchange rate.

In fact, because of the asset market function of the parallel exchange market, the parallel market rate can trade at a large premium over the official rate, even when the official rate is close to its long-run equilibrium value, that is, the value that equilibrates the balance of payments in "normal" macroeconomic circumstances. As noted above, this is because during periods of heavy capital outflows, the short-run equilibrium real exchange rate in a unified exchange market may depreciate relative to its long-run level; if the official exchange rate remains at that (i.e. equilibrium) long-run level, an excess demand for foreign exchange will develop that will cause a parallel market premium to emerge. The Latin American countries' experiences with exchange controls may fit this scenario. As will be discussed further below, in various of these countries, a combination of factors led to a balance-of-payment crisis in the 1980 s. The governments responded to this crisis by depreciating the official exchange rate, but because of the size of the capital outflows triggered by the crises, the parallel market rates in these countries depreciated still further.

Finally, we should underscore the fact that even if the real parallel market exchange rate, on average over long periods of time, were a good indicator of the long-run equilibrium real exchange rate, the value of the real parallel market rate at any single point in time would likely be an extremely unreliable proxy for that equilibrium rate. This is because the parallel market exchange rate, like any other asset price, depends upon highly volatile portfolio demands, and hence is itself highly volatile. This volatility may be seen quite easily in the charts of the official and parallel exchange rates presented at the end of this paper. Hence, aside from the fact that the parallel rate is likely to be a biased indicator of the long-run equilibrium exchange rate, it is also, unless averaged over 
very long periods, likely to be a highly uncertain or inaccurate indicator of the equilibrium rate as well. ${ }^{14}$

\section{Trends in Official and Parallel Real Exchange Rates}

The theoretical model described above suggests that the paraliel exchange rate is likely to be more depreciated than the long-run equilibrium real exchange rate, unless (1) macroeconomic factors inducing capital flight are not present, (2) exchange controls are poorly enforced, and/or (3) there are high import barriers that are well enforced. To evaluate these hypotheses, we would, ideally, compare the path of the parallel exchange rate in various countries to that of the long-run equilibrium real exchange rate in order to gauge the extent to which the parallel rate may serve as a useful guide to determining the equilibrium exchange rate and , therefore, in setting the official rate.

Unfortunately, the equilibrium real exchange rate is a theoretical construct which must be estimated, not a measured quantity for which data exist. Moreover, even in a unified market, the empirical estimation of the equilibrium real exchange rate is no easy task. Estimating the equilibrium rate is a highly involved process requiring strong assumptions about the operation of the current and capital accounts, as well as the estimation of stable trade and payments relationships over time $e^{15}$.

Estimation of the long-run equilibrium real exchange rate for a wide set of countries, in order to compare those exchange rates to actual parallel rates, would go beyond the limited scope of this paper. As a first step toward identifying where parallel market rates stand in relation to long-run equilibrium real exchange rates,

\footnotetext{
${ }^{14}$ Based on an optimizing model of the parallel market exchange rate, Montiel and Ostry (1994) come to much the same conclusion. They find that in the transition between steady-state equilibria in response to a productivity shock, the parallel market premium may move both above and below zero, and hence is "an unreliable indicator of the sign and magnitude of real exchange rate misalignment."

${ }^{15}$ A number of approached have been tried in the literature. Devarajaran (1995) uses a general equilibrium model that factors in changes in terms of trade to estimate the equilibrium real exchange rate and the extent of overvaluation in the CFA countries; Baffes et al (1995) construct an econometric model using a variety of macroeconomic fundamentals for several of these countries; Ahlers and Hinkle (1995) follow a trade elasticities approach in their estimation .
} 
however, it makes sense to compare levels of the parallel rate to levels of the official rate, averaged over long periods of time. This comparison may be informative, since over sufficiently long periods, the balance of payments must on average be at a sustainable level. Additionally, it may be useful to compare the level of the real official exchange rate during periods when exchange controls are in effect, and hence parallel markets exist, to periods when exchange markets are unified. Such comparisons may shed light on the factors that motivated the imposition of exchange controls, which in turn may have implications for the relationship between the parallel and equilibrium real exchange rates.

A complicating factor in using averages of actual exchange rates as proxies for equilibrium exchange rates is that for most countries, the process of development and structural change will cause the long-run equilibrium exchange rate to change over time. In that sense, a long period average of actual real exchange rates may yield, at best, an average of long-run real equilibrium exchange rates over that period. With this caveat in mind, however, we still believe that empirical comparisons of actual official and parallel exchange rates can yield useful insights.

First, our analysis will focus on averages of exchange rates across a large set of different countries. Therefore, even if long-run real equilibrium exchange rates follow particular trends in each individual country, the average long-run real equilibrium exchange rate for the sample as a whole may be more stationary. Second, our analysis focuses upon comparison of different types of exchange rates--official and parallel--during different regimes--with and without exchange controls. Therefore, our results will be vulnerable to misinterpretation mainly if the timing of exchange control periods in the sample coincide with particular movements in long-run equilibrium real exchange rates. While we believe, as discussed above, that exchange control periods are likeily to coincide with systematic movements in short-run equilibrium real exchange rates, as a result of temporary shocks to capital flows or the terms of trade, we have much less cause to believe that exchange controls have been associated with particular trends in long-run equilibrium real exchange rates.

\section{V.I Data and Methodology}


To make these comparisons, we gathered data on the official and parallel exchange rates for a sample of 24 developing countries (See Appendix 1 for the complete list). Of these, twelve are from Latin America, ten are African and two are South Asian. The sample is based on one chosen for an earlier World Bank research project on the macroeconomic implications of multiple exchange rates (see footnote 3 above). The sample is considered to be fairly representative - geographically and with respect to the alternative paths of evolution of the parallel market. The sample does include most of the more prominent developing countries with significant parallel markets, outside eastern and central Europe and the former Soviet Union. The basic data set is the one used in Ghei and Kiguel (1992). We added three African countries - Algeria, Malawi and Sudan ; and extended the data set to the last quarter of 1994.

To meaningfully compare levels of exchange rates over time, we first corrected the data for changes in prices by calculating real exchange rates. There are a number of empirical definitions of the real exchange rate (see Hinkle and Nsengiyumva (1995) for a detailed discussion). We use the bilateral real exchange rate between the country we are examining and the United States (local currency per US dollar-an increase in the exchange rate indicates depreciation). The consumer price index is used as a proxy for domestic prices; the US producer price index for world prices.

$$
e=\frac{E \cdot P^{U S}}{P}
$$

where $\mathbf{e}$ is the real exchange rate, $\mathbf{E}$, the nominal exchange rate, is the local currency value of U.S. dollar, $\mathbf{P}^{\text {us }}$ is the US producer price index and $\mathbf{P}$ is the domestic $\mathrm{CPI}^{16}$.

\footnotetext{
${ }^{16}$ It is conceivable that the use of a bilateral exchange rate, using the US producer price index as a proxy for world prices may bias our results, in view of the significant movements of the US dollar vis-a-vis other industrial countries during the 1980s. Results of tests for sensitivity with respect to choice of foreign price index are presented in Appendix 3, for a sub-sample of countries for the period 1979-94.
} 
The data used are end of quarter, for the period from 1970 through $1994^{17}$. The real official exchange rate is indexed so that $1985 \mathrm{Q} 1$ is equal to 100 . The real parallel market exchange rate is indexed so that its value in 1985 Q1 is equal to 100 pius the premium (in percent) of the parallel rate over the official rate in that base quarter. For each country, mean and the median average values are calculated for the following: $e$, the official real exchange rate for the entire period; $e^{p}$, the parallel real exchange rate for the entire period of its existence, that is, when exchange controls were in effect; $e^{\text {av }}$, the official non-unified real exchange rate, for the periouds when exchange controls were in effect and exchange markets were not unified; and $e^{*}$, the official real exchange rate during periods, if any existed, when exchange markets were unified. A unification of exchange markets is defined to have taken place if the absolute value of the parallel rate deviates less than 3 per cent from the official rate for at least 4 quarters. The non-zero number is to take into account measurement errors, since the official and parallel rates are from different sources (see tables).

A cross-country summary of our calculations of the four real exchange rate categories described above, based on mean averages of the exchange rate data for each separate country, is presented in columns 1 through 4 of Table 3. Results are presented in Table 3 for the whole sample, as well as two subsets. For the countries in each subset, we present the mean, median, and standard deviation of the real exchange rate. In columns 5 though 9 of Table 3, we calculate various ratios of the data shown in columns 1 through 4 , and perform binomial sign tests to determine whether these ratios differ significantly from one. The $\operatorname{Pr}$ (Ho is true) row indicates the probability that the observed configuration of ratios would be observed, if the null hypothesis - that the ratio were equal to 1 - were true.

The regional groupings were chosen in order to test our hypotheses concerning the different motivation and function of parallel markets in different regions. In Latin America and Turkey, exchange controls were imposed, particularly in the 1980s, in situations of macroeconomic and balance-of-payments crisis leading to

\footnotetext{
${ }^{17}$ The official exchange rates and prices are from IMF, International Financial Statistics. The parallel exchange rates are from World Currency Yearbook and International Currency Analysis, Inc.
} 
strong capital outflows. In these countries, pressures from capital flight are likely to have caused the parallel rate to depreciate weil above the long-run equilibrium real rate, even if the official exchange rate was not especially overvalued relative to its long-run equilibrium value. Afrrican and South Âsian countries, on the other hand, experienced much less macroeconomic distress. In those countries, exchange controls were more likely to have arisen as a means of rationing foreign exchange receipts in the context of a progressive overvaluation of the official exchange rate. As described in Section IV.2, the parallel rate is likely to be more depreciated than the long-run equilibrium rate in this context as well, unless exchange controls are poorly enforced and/or wellenforced import barriers effectively curtail the demand for foreign exchange.

\section{V.2 Comparisons of Period Averages}

We now compare the real parallel rate $\mathrm{e}^{\mathrm{p}}$ to various proxies of the equilibrium real exchange rate. The first possible proxy for the equilibrium RER we consider is e, the average RER for a period of twenty five years. As may be seen in column 5 , e $\%$ /e, on average, is greater than 1 , with a mean of 1.64 for the entire sample. In fact, there is no country in our sample for which the average real parallel market exchange rate was more appreciated than the average real official rate (calculated for periods when the exchange market was unified as well as nonunified). To the extent that the average official rate, when averaged over a sufficiently long period, is a good proxy for the equilibrium real rate, this suggests that the parallel rate is a biased indicator of the equilibrium rate.

However, using the average RER for the entire period may be misleading, since it includes periods with exchange controls as well as when the exchange market is unified. When exchange controls are in place, the nominal price of foreign exchange is set by the authorities, and access to foreign exchange is determined by quantitative rationing. Hence, the official real exchange rate during periods of exchange control is likely to be more appreciated than the equilibrium real rate. It may be more appropriate to use the RER averaged over periods of unified exchange markets - that is, $\mathrm{e}^{\mathrm{e}}$ - as a proxy for the long-run equilibrium RER.

For the whole sample, the parallel rate is, on average, more depreciated than the unified official RER; as indicated in column 8 , the mean of the ratio, $\mathrm{e}^{\mathrm{p}} / \mathrm{e}^{\prime}$, is 1.43 for all countries. However, this result masks strong 
differences between Latin America and Turkey, with a mean of 1.58, and Africa and Asia, with a mean value of 1.05 (which is not significantly different from 1). Hence, to the extent that $e^{*}$ is a good proxy for the long-run equilibrium real exchange rate, $e^{p}$ appears, on average, to have been close to the long-run equilibrium exchange rate in Africa and Asia, but much more depreciated than the long-run equilibrium level in Latin America and Turkey. This may seem surprising, given the far higher average parallel premia that have been observed in much of Africa; as shown in column 7, the ratio of the parallel market rate to the official rate during periods of exchange control averaged 1.85 for Africa and Asia but only 1.42 for Latin America and Turkey.

The strong differences in $\mathrm{e}^{\mathrm{p}} / \mathrm{e}^{\mathrm{e}}$, the ratio of the parallel rate to the unified official rate, between Latin America and Africa appear to be related to equally marked differences in the evolution of the official exchange rate between the two regions. As indicated in column 9, in Latin America and Turkey, the real official exchange rate tended to be more depreciated during periods of exchange controls than during periods when the exchange markets were unified; the mean ratio of $\mathrm{e}^{\mathrm{ut}} / \mathrm{e}^{\mathrm{v}}$ was 1.12 , with 9 of the 12 countries having ratios greater than 1 . This is consistent with our view that in Latin America and Turkey, unsustainable policies resulted in macroeconomic disequilibrium, which, in turn, triggered capital outflows which depreciated the short-run equilibrium real exchange rate (a relationship that would hold in a unified exchange market) relative to its longrun level. The government did depreciate the official exchange rate, but not by as much as the short-run equilibrium rate depreciated. Therefore, an excess demand for foreign exchange developed, causing the parallel rate to depreciate as well. As macro pressures eased, capital outflows moderated and reversed themselves, leading to an appreciation of the short-run equilibrium exchange rate and facilitating the unification of exchange markets.

In contrast to Latin America and Turkey, in the African and South Asian countries in our sample, the real official exchange rate tended to be more appreciated when exchange controls were in place than when exchange markets were unified. As shown in column 9, for Africa and South Asia, the ratio of $\mathrm{e}^{\mathrm{an}} / \mathrm{e}^{\mathrm{n}}$ was only .65, with all 5 countries in this grouping showing ratios less than 1 . This evidence, while qualified by the low number of observations in the sub-sample, supports our speculation that the emergence of a parallel market in Africa and 
Asia was typically the result of an appreciation of the real official exchange rate relative to the long-run equilibrium rate. Authorities chose, for a variety of reasons, to ration foreign exchange while maintaining an overvalued real exchange rate. As the extent of overvaluation increased, often foreign exchange rationing tightened, and the parallel market grew, as did the premium.

Considering how overvalued the real official exchange rate was in many African and the South Asian countries, relative to its long-nun equilibrium value, it is surprising that real parallel rates in those countries were not more depreciated compared with average real official exchange rates during the periods when exchange markets were unified. Section IV. 2 showed that, all else equal, the more overvalued was the official exchange rate, the more undervalued would be the parallel rate relative to the long-run equilibrium rate. Therefore, unification presumably would have required African and Asian government to devalue their official exchange rates to a level that was not as depreciated as the prior level of the parallel rate.

In addressing this issue, it is important to point out that we have a very small sample to examine - only 5 countries in our sample in the subset, Africa and South Asia, unified their exchange rates. In two of these five cases (Egypt and Tanzania), the ratio is greater than 1. Additionally, as we pointed out in Section IV.2, there are factors that may lower the parallel rate relative to the level predicted by the basic model. First, consider the case when under invoicing, $\phi$, is high because exchange controls are not effective - when enforcement is lackadaisical and evasion widespread. Then, for all practical purposes, the relevant rate for the economy becomes the parallel rate, which may, in this case, be close to the equilibrium rate. Then, when exchange markets are unified, the official rate would need to be depreciated to the level of the former parallel rate, and $\mathrm{e}^{\mathrm{p}} / \mathrm{e}^{\mathrm{A}}$ would be close to one. Ghana is an excellent illustration for this (Chibber and Shaffik (1991)).

A second factor that might appreciate the parallel market rate relative to the level predicted by the basic model might be the strong enforcement of import controls. This would cause the premium to be low, even if the official exchange rate is maintained at a substantially overvalued level compared with the long-run equilibrium exchange rate, since effective import controls reduce the demand for foreign exchange and thereby appreciate the 
short-run equilibrium exchange rate. Then, if unification is associated with import liberalization, thereby depreciating the short-run real equilibrium exchange rate, the official exchange rate will have to depreciate by a large amount if excess demands for foreign exchange are to be eliminated. This scenario would lead to a ratio,

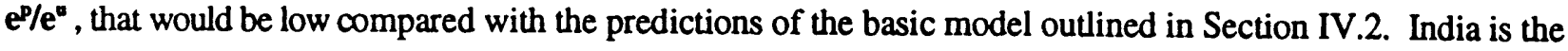
best example for this -unification of the exchange rate took place in 1993 as part of a larger liberalization efrort, requiring a greater devaluation of the official exchange rate than would have been the case in the absence of import liberalization.

Table 3: Full Period Statistics, Ratios and Binomial Sign Tests

\begin{tabular}{|c|c|c|c|c|c|c|c|c|c|}
\hline & 1 & 2 & 3 & 4 & 5 & 6 & 7 & 8 & 9 \\
\hline Country & $\begin{array}{c}\text { Official } \\
\text { Real ER } \\
1970-94 \\
\end{array}$ & $\begin{array}{l}\text { Parallel } \\
\text { Real ER }\end{array}$ & $\begin{array}{c}\text { Official } \\
\text { ER with } \\
\text { Par. mkt }\end{array}$ & $\begin{array}{c}\text { Official } \\
\text { ER when } \\
\text { unified }\end{array}$ & $\begin{array}{c}\text { Ratio, } \\
\mathrm{e}^{\mathrm{p} / \mathrm{e}} \\
\mathbf{2} / \mathbf{1} \\
\end{array}$ & $\begin{array}{c}\text { Ratio, } \\
e^{\mathrm{m} /} / \mathbf{e} \\
\mathbf{3 / 1} \\
\end{array}$ & 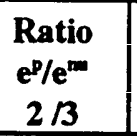 & $\begin{array}{c}\text { Ratio, } \\
e^{P / e^{*}} \\
2 / 4 \\
\end{array}$ & $\begin{array}{c}\text { Ratio, } \\
\mathrm{e}^{\mathrm{me} / \mathrm{e}^{*}} \\
3 / 4 \\
\end{array}$ \\
\hline \multicolumn{10}{|c|}{ Latin America and Turkey } \\
\hline Mean & 82.52 & 121.02 & 85.13 & 76.91 & 1.46 & 1.03 & 1.42 & 1.58 & 1.12 \\
\hline Median & 69.10 & 115.01 & 69.43 & 64.66 & 1.24 & 1.06 & 1.36 & 1.32 & 1.10 \\
\hline Std Dev & 26.17 & 24.29 & 47.71 & 27.28 & 0.36 & 0.26 & 0.34 & 0.39 & 0.16 \\
\hline Number $\leq 1$ & & & & & 9 & 3 & 0 & 0 & 3 \\
\hline Number $>1$ & & & & & 12 & 9 & 12 & 12 & 9 \\
\hline $\mathrm{Pr}\left(\mathrm{H}_{0}\right.$ is irue $)$ & & & & & 0.0002 & 0.019 & 0.0002 & 0.0002 & 0.019 \\
\hline \multicolumn{10}{|l|}{ Africa \& Asia } \\
\hline Mean & 120.04 & 222.82 & 117.94 & 195.24 & 1.82 & 0.98 & 1.85 & 1.05 & 0.65 \\
\hline Median & 103.56 & 186.64 & 101.56 & 267.03 & 1.78 & 1.00 & 1.81 & 0.97 & 0.57 \\
\hline Std Dev & 45.99 & 111.76 & 45.03 & 85.81 & 0.58 & 0.02 & 0.58 & 0.18 & 0.12 \\
\hline Number $\leq 1$ & & & & & o & 12 & q & 3 & 5 \\
\hline Number $>1$ & & & & & 12 & 0 & 12 & 2 & 0 \\
\hline $\mathrm{Pr}$ ( $\mathrm{H}_{0}$ is true $)$ & & & & & 0.0002 & 0.0002 & 0.0002 & 0.500 & 0.031 \\
\hline \multicolumn{10}{|l|}{ All countries } \\
\hline Mean & 101.28 & 171.92 & 101.53 & 111.71 & 1.64 & 1.01 & 1.64 & 1.43 & 0.99 \\
\hline Median & 91.38 & 131.33 & 91.10 & 86.24 & 1.52 & 1.00 & 1.54 & 1.36 & 1.07 \\
\hline Std Dev & 41.60 & 99.81 & 40.40 & 74.67 & 0.50 & 0.04 & 0.51 & 0.38 & 0.25 \\
\hline Number $\leq 1$ & & & & & 0 & 15 & 0 & 3 & 8 \\
\hline Number $>1$ & & & & & 24 & 9 & 24 & 14 & 9 \\
\hline $\mathrm{P}_{\overline{\mathrm{I}}}\left(\mathrm{H}_{0}\right.$ is true $)$ & & & & & 0.000 & 0.153 & 0.000 & 0.006 & 0.500 \\
\hline
\end{tabular}

Source: IFS, World Currency Yearbook, Currency Analysis Inc, various issues, authors calculations. 


\section{V.3 The Official Exchange Rate after Exchange Market Unification}

The issues related to unification can be further examined by considering what happens to the official exchange rate at that time. We have twenty observations of unifications. In some cases, a country has two episodes of dual exchange rates, with a period of unified exchange rates in the interim; these are treated as two separate observations. Some countries have never unified, and therefore are not represented (see Appendix 2 for the complete list). The composition of the unification data set is quite different from that used in Table 1. Firstly, three-quarters of the observations are from the experience of unification in Latin America; only three out of the twenty observations are for Africa, with the two South Asian countries completing the count. The very small sample means that the subsets results are to be interpreted with caution for the Africa and South Asia subset.

In Table 4, we look at the mean, median and standard deviation of three variables: the average official RER for the year before the unification (10), the average official RER in the year following unification (11) and the average parallel rate for the year preceding the unification (12). We calculate two ratios, of the postunification official RER to the pre-unification RER, $\mathbf{e}^{*}{ }_{t+1} / \mathrm{e}^{\mathrm{ne}} \mathrm{t-1}$; and the ratio of the post unification official (and sole) RER to the pre-unification parallel rate, $\mathrm{e}^{\mathrm{n}}{ }_{\mathrm{t}+1} / \mathrm{e}_{\mathrm{t}-1}^{\mathrm{p}}$. As before, we report the mean, median and standard deviation for all variables as well as the results of binomial sign test for the ratios.

The results are consistent with the findings reported in table 3. The ratio of the post- to pre-unification official exchange rate, $e^{n}{ }_{t+1} / \mathrm{e}^{n *}{ }_{t-1}$, is approximately equal to one for the whole sample. Again, aggregation obscures the difference in results between the two subsets. The ratio, $\mathrm{e}_{t+1} / \mathrm{e}^{\mathrm{an}}{ }_{\mathrm{t}-1}$ is (very) slightly less than 1 for Latin America and Turkey, suggesting a small appreciation in the RER following unification. This is consistent with the idea than capital inflows resumed as the macro crisis was alleviated, appreciating the short-run real equilibrium exchange rate and allowing the authorities to appreciate the real official exchange rate while simultaneously unifying the exchange markets. The ratio is slightly greater than 1 on average for Africa and Asia, as the exchange rate was devalued following unification. Again, this is consistent with the observation that in these countries, official exchange rates during the exchange control period were overvalued relative to their long- 
run equilibrium rates, so that unification required the devaluation of the official rate.

The relationship between the unified official rate and the prior parallel rate also differs somewhat among the sub-samples. The ratio $e^{n}{ }_{t+1} / \mathbf{e}^{p}{ }_{t-1}$ clearly is less than 1 for the entire sample, indicating that in general, the official rate is not depreciated all the way to the level of the former parallel rate. With the exception of Ghana and Bolivia, the average ratio is less than 1 for all countries. This result also is unambiguous for the Latin America and Turkey subset. On the other hand, the ratio $\mathrm{e}_{t+1} / \mathrm{e}^{\mathbf{p}}{ }_{t-1}$ does not appear to be significantly different from one for the African and Asian sample, which is consistent with results described above--average unified official exchange rates appear to be close to the average level of the parallel rate in Asia and Africa.

Table 4: Unification Episodes - Statistics, Ratios and Binomial Sign Tests

\begin{tabular}{|c|c|c|c|c|c|}
\hline & 10 & 11 & 12 & 13 & 14 \\
\hline Country & $\begin{array}{c}\text { Oficial RER, } \\
\text { Year, unif-1 }\end{array}$ & $\begin{array}{l}\text { Official RER, } \\
\text { Year, unif }+1\end{array}$ & $\begin{array}{c}\text { Parallel RER, } \\
\text { Year, unif-1 }\end{array}$ & $\begin{array}{c}\mathrm{e}^{\mathrm{n}}{ }_{t+1} / \mathrm{e}^{\mathrm{nex}}{ }^{1-1} \\
11 / 10 \\
\end{array}$ & $\begin{array}{c}e^{u}{ }_{t+1} / \mathrm{e}^{\mathrm{p}}{ }_{t-1} \\
11 / 12 \\
\end{array}$ \\
\hline \multicolumn{6}{|c|}{ Latin America \& Turkey } \\
\hline Mean & 85.15 & 85.62 & 109.31 & 1.00 & 0.83 \\
\hline Median & 81.99 & 75.74 & 101.98 & 0.98 & 0.87 \\
\hline Std Dev & 29.89 & 33.19 & 54.88 & 0.09 & 0.15 \\
\hline Number $\leq 1$ & & & & 9 & 15 \\
\hline Number $>1$ & & & & 7 & 1 \\
\hline $\operatorname{Pr}\left(\mathrm{H}_{0}\right.$ is true $)$ & & & & 0.576 & 0.001 \\
\hline \multicolumn{6}{|l|}{ Africa \& Asia } \\
\hline Mean & 183.67 & 201.50 & 203.81 & 1.08 & 0.98 \\
\hline Median & 172.71 & 155.21 & 180.99 & 1.11 & 0.94 \\
\hline Std Dev & 71.92 & 87.56 & 85.81 & 0.12 & 0.13 \\
\hline \multicolumn{6}{|l|}{ Number $\leq 1$} \\
\hline Number $>1$ & & & & 4 & 1 \\
\hline $\operatorname{Pr}\left(\mathrm{H}_{0}\right.$ is true $)$ & & & & 0.188 & 0.188 \\
\hline \multicolumn{6}{|l|}{ All countries } \\
\hline Mean & 108.61 & 113.21 & 131.81 & 1.02 & 0.86 \\
\hline Median & 99.42 & 83.77 & 118.08 & 1.00 & 0.90 \\
\hline Std Dev & 60.60 & 71.42 & 75.28 & 0.11 & 0.16 \\
\hline Number $\leq 1$ & & & & 10 & 19 \\
\hline Number $>1$ & & & & 11 & 2 \\
\hline $\operatorname{Pr}\left(\mathrm{H}_{0}\right.$ is true $)$ & & & & 0.500 & 0.0001 \\
\hline
\end{tabular}

Source: IFS, World Currency Yearbook, Currency Analysis Inc, various issues, autbors calculations. 


\section{Conclusion}

We now summarize the most important findings presented in our paper. To begin with, our theoretical analysis indicated that when the emergence of a parallel exchange market is motivated by the overvaluation of the official exchange rate relative to the long-run equilibrium real exchange rate, the parallel market rate is likely, on average, to be more depreciated than the long-run equilibrium real exchange rate. The gap between the parallel rate and the long-run equilibrium rate is likely to be smaller, to the extent that export receipt surrender requirements are not well-enforced, and to the extent that barriers to imports and other commercial policies that tend to appreciate the short-run equilibrium real exchange rate are well-enforced.

Moreover, our theoretical analysis indicated that even if the official exchange rate is set at its long-run equilibrium level, a parallel market may arise in order to meet the demands of residents seeking to augment their holdings of foreign assets. During the period when foreign assets are being accumulated--that is, when capital flight is occurring--the parallel exchange rate will be more depreciated than its own equilibrium value, and hence probably more depreciated than the long-run equilibrium exchange rate for the economy as a whole. Additionally, because the parallel market rate is an asset price, and exhibits the volatility that is characteristic of all asset prices, the value of the parailei rate at any given moment is likeiy to be a particularly poor indicator of the long-run equilibrium exchange rate.

These considerations suggest that on balance, the parallel rate is likely to be more depreciated than the long-run equilibrium real exchange rate, and hence the official exchange rate in a unified exchange market will in general best be set at a level that is more appreciated than the prior parallel rate (averaged over a suitably long period). In this paper, we did not compare actual parallel exchange rates to estimates of the long-run equilibrium rate in different countries, owing to the difficulty of estimating equilibrium rates for a large sample. However, we compared multi-year averages of real parallel rates to real official rates in a sample of 24 developing countries, and made a number of useful findings.

First, we found that for the sample as a whole, the real parallel market rate was uniformly more 
depreciated than the official exchange rate, even when the official rate was measured only during periods when the exchange markets were unified. During periods when the exchange market is unified, and there are no exchange controls to bridge the gap between supplies and demands for foreign exchange, the official exchange rate is more likely to be close to the long-run equilibrium rate on average. Hence, this represents partial evidence that the parallel rate tends to be undervalued relative to the long-run equilibrium exchange rate.

Second, we found important differences in the relationship between parallel and official exchange rates among different subsets of our country sample. In Latin America and in Turkey, the emergence of parallel exchange markets appears to have reflected a sharp depreciation of the short-run equilibrium exchange rate relative to its long-run value, not the appreciation of the official exchange rate from its long-run equilibrium value. In those countries, the parallel rate was clearly depreciated compared with the official exchange rate during periods when the exchange markets were unified. However, the undervalued nature of the parallel rate does not appear to have reflected the overvaluation of the official exchange rate relative to the long-run equilibrium real exchange rate during periods of exchange controls, since the official exchange rate in this subset was on average more depreciated during the periods when exchange controls were in effect than in the periods when markets were unified.

We surmise that a combination of internal and external shocks led to macroeconomic turbulence and capital flight in Latin America and Turkey, mainly in the 1980s. These developments, in turn, depreciated the short-run equilibrium real exchange rate relative to its long-run level. While the authorities depreciated their official exchange rates-possibiy even to leveis more depreciated than the long-run equilibrium rate--they did not do so by enough to resolve excess demands for foreign exchange. That is, even if official exchange rates during the exchange control period were undervalued relative to the long-run equilibrium rate, they were overvalued relative to the short-run equilibrium rate, thereby giving rise to parallel exchange markets. As a result, the parallel rates probably were even more undervalued relative to the long-run equilibrium rate than were the official rates. 
Third, we found that the African and South Asian countries in our sample better fit our preconception that the emergence of parallel exchange markets reflects the overvaluation of the official exchange rate relative to its long-run equilibrium value. Among the few countries in this subset that experienced periods of unified exchange rates, the real official exchange rate clearly was more appreciated during periods when exchange controls were in effect than in periods when exchange markets were unified. This suggests that in contrast to the Latin America and Turkey case, the real appreciation of official exchange rates in Africa and South Asia, relative to long-run equilibrium values, was the main factor underlying the emergence of parallel markets.

On the other hand, in Africa and South Asia, the parallel exchange rate was not significantly more depreciated than the official exchange rate during periods when markets were unified--put another way, when exchange markets were unified, the authorities had to depreciate the official rate all the way to the level of the former parallel rate. The relative similarity of parallel and unified official exchange rates underscores the fact that in the case of some African countries, exchange controls may have been so poorly enforced that the parallel rate effectively mimicked the role of the official rate in a unified exchange market. Additionally, in some Asian countries, well-enforced import barriers constrained the demand for foreign exchange when exchange controls were in effect, thereby appreciating both the short-run equilibrium exchange rate and the parailei rate; exchange markets were unified at about the same time as import barriers were lowered, making it necessary to depreciate the official exchange rate substantially in order to maintain the balance of payments in a unified market.

Our findings for some African and Asian countries suggest that in some cases, the parallel rate might not be an inappropriate proxy for the long-run equilibrium exchange rate, and hence could be a guide to setting the official rate. Somewhat special factors were operative in these countries however--very poorly enforced exchange controls in some African countries, very well-enforced import controls in some Asian countries. More generally, the parallel market rate would seem to represent an upper bound, in terms of local currency per dollar, on the appropriate level of the official exchange rate. 


\section{REFERENCES:}

Agenor, Pierre-Richard (1992), Parallel Currency Markets in Developing Countries: Theory, Evidence, and Policy Implications, Princeton Essays in International Finance No. 188, Princeton, N.J.

Ahlers T.O., and L.E. Hinkle (1995), "Estimating the equilibrium real exchange rate: an updated resource balance target/ trade elasticities approach", World Bank, Washington DC, forthcoming.

Baffes, J., I.A. Elbadawi and S.A. O'Connell (1995), "Econometric estimates of the equilibrium RER", World Bank, Washington DC, forthcoming.

Chibber, A., and N. Shaffik (1991), "Exchange reform, parallel markets and inflation in Africa: the case of Ghana", in A.Chibber and S. Fischer, eds, Economic Reform in Sub-Saharan Africa, World Bank, Washington DC.

Devarajan, S. (1995), "Estimation of RER misalignment using the 1-2-3 model", World Bank, Washington DC, forthcoming.

Dornbusch, R., D.V. Dantos, C. Pechman , R.R. Rocha and D. Simoes (1983), "The black market for dollars in Brazil", Quarterly Journal of Economics, Vol 98, pp. 25-40.

Ghei, N., and M.A. Kiguel, (1992), "Dual and multiple exchange rate systems in developing countries: some empirical evidence", Policy Research Working Paper Number 881, The World Bank, Washington DC.

and S.A. O'Connell (1996), "Parallel exchange rates in developing countries: lessons from eight case studies" in M.A. Kiguel, J.S. Lizondo and S.A. O'Connell,eds, Parallel Exchange Rates in Developing Countries, MacMililan, London and St. Martin's Press, New York.

Hinkle, L.E., and F. Nsengiyumva (1995), "Real exchange rate indexes: a user's guide to their theoretical definition, empirical measurement and interpretation", World Bank, Washington DC, processed, May 8, 1995.

Kamin , S.B. (1995), "Contractionary devaluations with black markets for foreign exchange", Journal of Policy Modeling, Vol.17, number 1, pp. 39-57

Kamin, S.B. (1993), "Devaluation, exchange controls and black markets for foreign exchange in developing countries, Journal of Development Economics, Vol 40, pp. 151-169.

Kiguel , M.A., and S.A. O'Connell (1995), "Parallel exchange rates in developing countries", World Bank Research Observer, Vol 10, number 1, pp 21-52.

Montiel, Peter J. and Jonathan D. Ostry (1994), "The parallel market premium: is it a reliable indicator of real exchange rate misalignment in developing countries?" IMF Staff Papers 41, pp.55-75.

Montiel, Peter J. (1996), "The theory of the long-run equilibrium real exchange rate," World Bank, Washington, DC, forthcoming.

Nowak, M. (1984), "Quantitative controls and unofficial markets for foreign exchange", IMF Staff Papers 31, pp. 404-31

Sheik, M.A. (1976), "Black market for foreign exchange, capital flows and smuggling", Journal of Development Economics, Vol 3, pp. 9-26. 


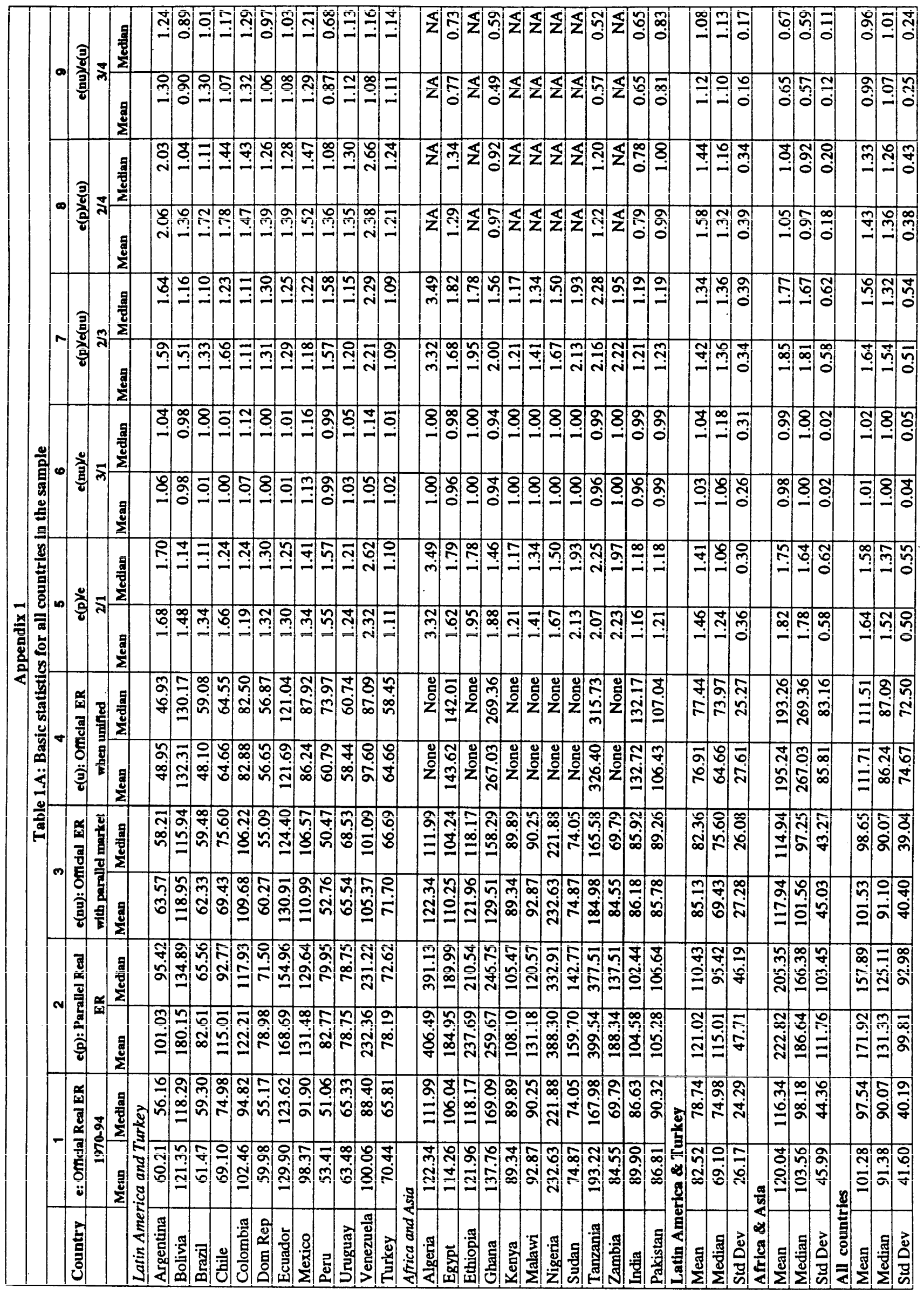




\section{Appendix 2}

Table 2.A: Unification Episodes

\begin{tabular}{|c|c|c|c|c|c|c|c|c|c|c|}
\hline Country & \multicolumn{2}{|c|}{10} & \multicolumn{2}{|c|}{11} & \multicolumn{2}{|c|}{12} & \multicolumn{2}{|c|}{13} & \multicolumn{2}{|c|}{14} \\
\hline & \multirow{2}{*}{\multicolumn{2}{|c|}{$\frac{\mathrm{e}(\mathrm{nu}, \mathrm{t}=1) \text { Omclal RER }}{\text { Year, Unification-1 }}$}} & \multicolumn{2}{|c|}{ o(u,t+1) Omclal RER } & \multicolumn{2}{|c|}{$e(\mathbf{p}, \mathbf{t - 1})$ Paralle! RER } & \multicolumn{2}{|c|}{$e(u, t+1) / e(n u, t=1)$} & \multicolumn{2}{|c|}{$\propto(u, t+1) / e(p, t=1)$} \\
\hline & & & \multicolumn{2}{|c|}{ Year, Unification+1 } & \multicolumn{2}{|c|}{ Year, Uniffcation-1 } & \multicolumn{2}{|c|}{$11 / 10$} & \multicolumn{2}{|c|}{$11 / 12$} \\
\hline & Míean & & Mean & Medhan & Mean & Mediañ & Mean & Mediañ & Mean & Median \\
\hline \multicolumn{11}{|c|}{ Latin America and Turkey } \\
\hline Argentina & 76.45 & 69.89 & 74.17 & 75.55 & 147.95 & 141.42 & 0.97 & 1.08 & 0.50 & 0.53 \\
\hline Argentina & 26.52 & 26.41 & 26.03 & 25.93 & 29.40 & 29.04 & 0.98 & 0.98 & 0.89 & 0.89 \\
\hline Bolivia & 126.58 & 126.10 & 136.51 & 136.50 & 135.79 & 134.01 & 1.08 & 1.08 & 1.01 & 1.02 \\
\hline Bolivia & 125.96 & 126.17 & 128.00 & 127.70 & 134.21 & 134.36 & 1.02 & 1.01 & 0.95 & 0.95 \\
\hline Brazil & 60.01 & 59.92 & 59.30 & 59.08 & 64.74 & 65.17 & 0.99 & 0.99 & 0.92 & 0.91 \\
\hline Chile & 58.23 & 57.82 & 64.18 & 64.31 & 65.00 & 65.32 & 1.10 & 1.11 & 0.99 & 0.98 \\
\hline Colombia & 99.42 & 99.68 & 83.77 & 84.26 & 104.46 & 104.28 & 0.84 & 0.85 & 0.80 & 0.81 \\
\hline Dom Rep & 57.21 & 56.98 & 56.12 & 56.36 & 61.18 & 60.92 & 0.98 & 0.99 & 0.92 & 0.93 \\
\hline Ecuador & 126.11 & 126.18 & 126.39 & 127.84 & 141.07 & 140.06 & 1.00 & 1.01 & 0.90 & 0.91 \\
\hline Mexico & 103.69 & 110.30 & 106.98 & 106.10 & 114.40 & 115.15 & 1.03 & 0.96 & .94 & .92 \\
\hline Mexico & 87.53 & 88.01 & 76.20 & 75.50 & 92.51 & 93.29 & 0.87 & 0.86 & 0.82 & 81 \\
\hline Peru & 64.50 & .99 & 75.28 & 75.01 & 132.37 & 146.55 & 1.17 & 1.17 & .57 & 51 \\
\hline Uruguay & 3.78 & 40 & 67.09 & 67.18 & 93 & 81.16 & 0.98 & 0.98 & 1.83 & 83 \\
\hline Venezuela & 128.77 & 108.14 & 149.58 & 149.64 & 277.38 & 272.90 & 1.16 & 1.38 & 0.54 & 0.55 \\
\hline Turkey & 64.49 & 65.59 & 57.84 & 58.19 & 11 & 68.22 & 0.90 & 0.89 & .85 & 0.85 \\
\hline Turkey & 88.19 & 87.38 & 82.40 & 83.32 & 9.50 & 97.95 & 0.93 & 0.95 & .83 & 0.85 \\
\hline \multicolumn{11}{|c|}{ Africa and Asia } \\
\hline Egypt & 172.71 & 171.70 & 155.21 & 156.55 & 180.99 & 176.55 & 0.90 & 0.91 & 0.86 & 0.89 \\
\hline Ghana & 212.66 & 212.93 & 266.21 & 271.59 & 217.60 & 223.52 & 1.25 & 1.28 & 1.22 & 1.22 \\
\hline Tanzani & 5.99 & 306.85 & 340.09 & 334.37 & 361.34 & 355.90 & 1.11 & 1.09 & 0.94 & 0.94 \\
\hline India & 120.01 & 119.88 & 138.24 & 138.99 & 141.04 & 140.95 & 1.15 & 1.16 & 0.98 & 0.99 \\
\hline Pakistan & 106.97 & 106.40 & 107.73 & 108.31 & 118.08 & 116.50 & 1.01 & 1.02 & 0.91 & 0.93 \\
\hline \multicolumn{11}{|c|}{ Latin America \& Turkey } \\
\hline Mean & 85.15 & 83.81 & 85.62 & 85.78 & 109.31 & 109.36 & 1.00 & 1.02 & 0.83 & 0.83 \\
\hline Median & 81.99 & 78.63 & 75.74 & 75.52 & 101.98 & 101.12 & 0.98 & 0.99 & 0.87 & 0.87 \\
\hline Std Dev & 29.89 & 28.91 & 33.19 & 33.22 & 54.88 & 54.17 & 0.09 & 0.13 & 0.15 & 0.15 \\
\hline \multicolumn{11}{|c|}{ Africa \& Asia } \\
\hline Mean & 183.67 & 183.55 & 201.50 & 201.96 & 203.81 & 202.68 & 1.08 & 1.09 & 0.98 & 0.99 \\
\hline Media & 172.71 & 171.70 & 155.21 & 156.55 & 180.99 & 176.55 & 1.11 & 1.09 & 0.94 & 0.94 \\
\hline Std Dev & 71.92 & 72.41 & 87.56 & 86.23 & 85.81 & 84.65 & 0.12 & 0.12 & 0.13 & 0.12 \\
\hline \multicolumn{11}{|c|}{ All countries } \\
\hline Mean & 108.61 & 107.56 & 113.21 & 113.44 & 131.81 & 131.58 & 1.02 & 1.04 & 0.86 & 0.87 \\
\hline Med & 99.42 & 99.68 & 83.77 & 84.26 & 118.08 & 116.50 & 1.00 & 1.01 & 0.90 & 0.91 \\
\hline Std Dev & 60.60 & 60.74 & 71.42 & 71.13 & 75.28 & 74.31 & 0.11 & 0.13 & 0.16 & 0.16 \\
\hline
\end{tabular}




\section{Appendix 3: Sensitivity of Results to choice of Real Exchange Rate}

The trends in section V are estimated using the US producer price index as a proxy for world prices. This may bias the results, particularly for time periods when movements in the US real exchange rate diverge significantly from those of other industrial countries, as they did over much of the 1980 s. We estimate the same ratios as in Table 3, using trade-weighted multilateral real exchange rates (see Tables 3.A and 3.B below).

The data were available in the International Financial Statistics database, of the IMF, for only ten of the twenty-four countries in our sample, for the time period 1979 to 1994 . While it would be possible to calculate multilateral real exchange rates for all the countries in the sample, for the period under consideration, this would be a laborious process. Further, this data set covers a shorter time period than the one used in the study (1970 to 1994). However, the real US \$ bilateral rate would have diverged significantly from the trade weighted multilateral rate primarily in the 1980s; this data set includes the period of interest. Therefore, we use the smaller data set readily available to compare the values obtained for the ratios we calculate using the bilateral real exchange rate with those for available trade weighted, multilateral real exchange rates.:

The use of multilateral exchange rates yield estimates of the ratios under consideration that are remarkably similar to those obtained using bilateral results. The one result that is different is the binomial sign test for the ratio, $\mathrm{e}^{\mathrm{nu}} / \mathrm{e}^{\star}$. The probability that Ho is true is much higher when the multilateral rate is used. This is probably due to the very small sample: just five observations. The orders of magnitude do not differ markedly for the measures of central tendency.

The choice of a bilaterai real exchange rate would not seem to impact on the results in any significant way. At the same time, using the bilatêral real exchange rate has other advantages. In particular, using the bilateral rate permits analysis for a larger sample of countries, for a longer time period. However, there are 
some instances where the differences in the values using the different real exchange rates are more than trivial (see Table 3.B. particularly Uruguay (columns 8 and 9, and Nigeria). If the analysis is to be done for a single country, the use of the trade-weighted muitilaterai real exchange rate would be preferable. For a sample as large as the one in this study, the advantages of using the bilateral real exchange rate are greater.

Table 3.A: Comparing Bilateral and Multilateral Exchange Rates

\begin{tabular}{|c|c|c|c|c|c|c|c|c|c|}
\hline & 1 & 2 & 3 & 4 & 5 & 6 & 7 & 8 & 9) \\
\hline Variable & $\begin{array}{c}\text { Orificial } \\
\text { Real ER } \\
\text { 1979-94 } \\
\text { e } \\
\end{array}$ & $\begin{array}{c}\text { Parallel } \\
\text { Real ER } \\
\mathrm{e}^{\mathrm{p}} \\
\end{array}$ & $\begin{array}{c}\text { Ofilicial } \\
\text { ER w } f \\
\text { Par mkt } \\
\mathrm{e}^{\mathbf{n u}}\end{array}$ & $\begin{array}{c}\text { Ofîcial } \\
\text { ER when } \\
\text { unified } \\
e^{*} \\
\end{array}$ & $\begin{array}{c}\text { Ratio } \\
\text { éc/e } \\
2 / 1 \\
\end{array}$ & $\begin{array}{r}\text { Râtiōo, } \\
e^{\text {nu/é }} \\
3 / 1 \\
\end{array}$ & 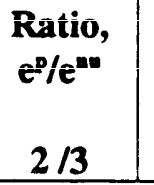 & $\begin{array}{c}\begin{array}{c}\text { Ratio, } \\
e^{p} / \epsilon^{*}\end{array} \\
2 / 4 \\
\end{array}$ & 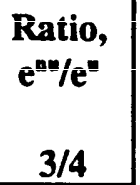 \\
\hline \multicolumn{10}{|c|}{ Summary Statistics } \\
\hline \multicolumn{10}{|l|}{ Mean } \\
\hline Biliateraì & 118.09 & $19 \hat{1} .01$ & 118.69 & 87.68 & 1.55 & 1.01 & 1.55 & 1.62 & 1.19 \\
\hline Multilateral & 175.73 & 279.88 & 172.69 & 149.36 & 1.53 & 1.00 & 1.56 & 1.50 & 1.10 \\
\hline \multicolumn{10}{|l|}{ Median } \\
\hline Bilateral & 106.28 & 168.57 & 104.21 & 72.18 & 1.36 & 1.00 & 1.36 & 1.60 & 1.19 \\
\hline Multilateral & 132.80 & 186.09 & 124.66 & 103.88 & 1.38 & 1.00 & 1.40 & 1.54 & 1.12 \\
\hline \multicolumn{10}{|c|}{ Standard Deviation } \\
\hline Bilateral & 54.66 & 116.71 & 54.10 & 35.74 & 0.37 & 0.06 & 0.42 & 0.25 & 0.31 \\
\hline Muitilaterai & 120.95 & 230.58 & 117.96 & 104.42 & 0.37 & 0.07 & 0.43 & 0.30 & 0.33 \\
\hline \multicolumn{10}{|c|}{ Binomial Sign Tests } \\
\hline \multicolumn{10}{|l|}{ Number $<=1$} \\
\hline Bilateral & & & & & 0 & 6 & 0 & 0 & 4 \\
\hline Multilateral & & & & & 0 & 8 & 0 & 1 & 3 \\
\hline \multicolumn{10}{|l|}{ Number $>1$} \\
\hline Bilateral & & & & & 10 & 4 & 10 & 6 & 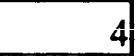 \\
\hline Mútiliateral & & & & & 10 & 2 & 10 & 5 & 3 \\
\hline \multicolumn{10}{|l|}{$\operatorname{Pr}\left(\mathrm{H}_{0}\right.$ is true $)$} \\
\hline Bilateral & & & & & 0.0001 & 0.377 & 0.0001 & 0.0156 & 0.3438 \\
\hline Multilateral & & & & & 0.0001 & 0.055 & 0.0001 & 0.1094 & 0.6563 \\
\hline
\end{tabular}

Source: IFS, World Currency Yearbook, Currency Analysis, Inc, various issues, authors calculations. 


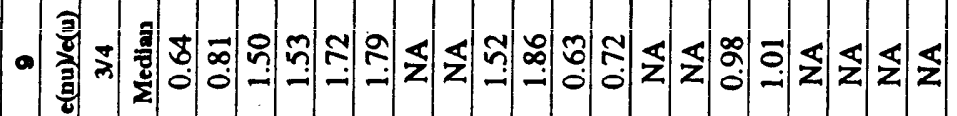

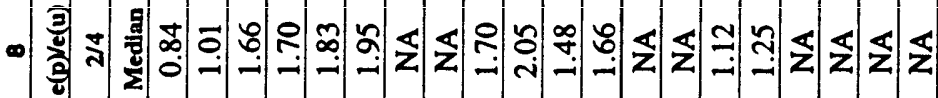

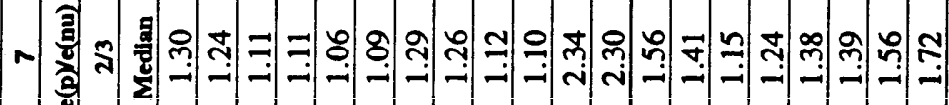

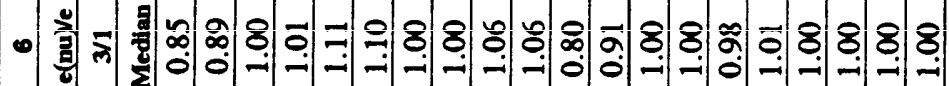

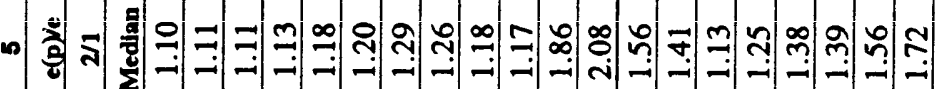

(2)

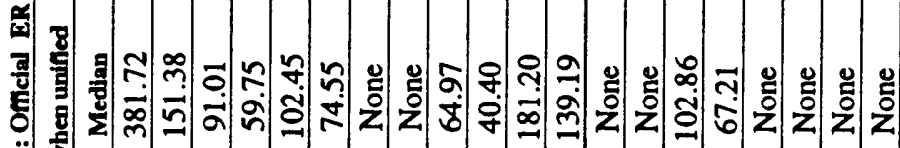
弟

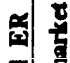



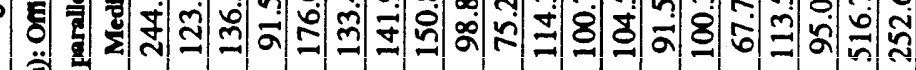
츨 N

苞

(a)

- 형 8 영

요

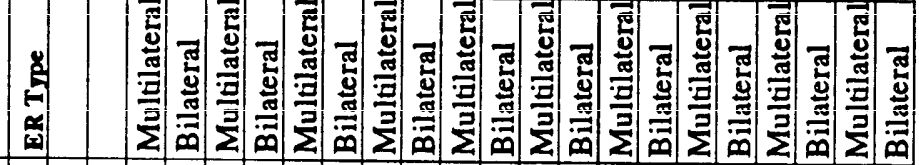

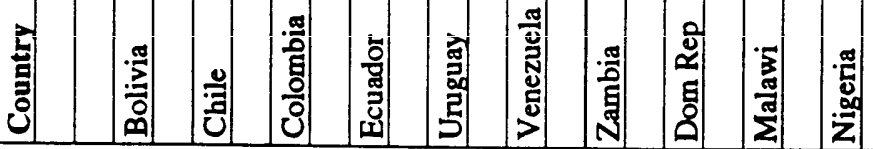





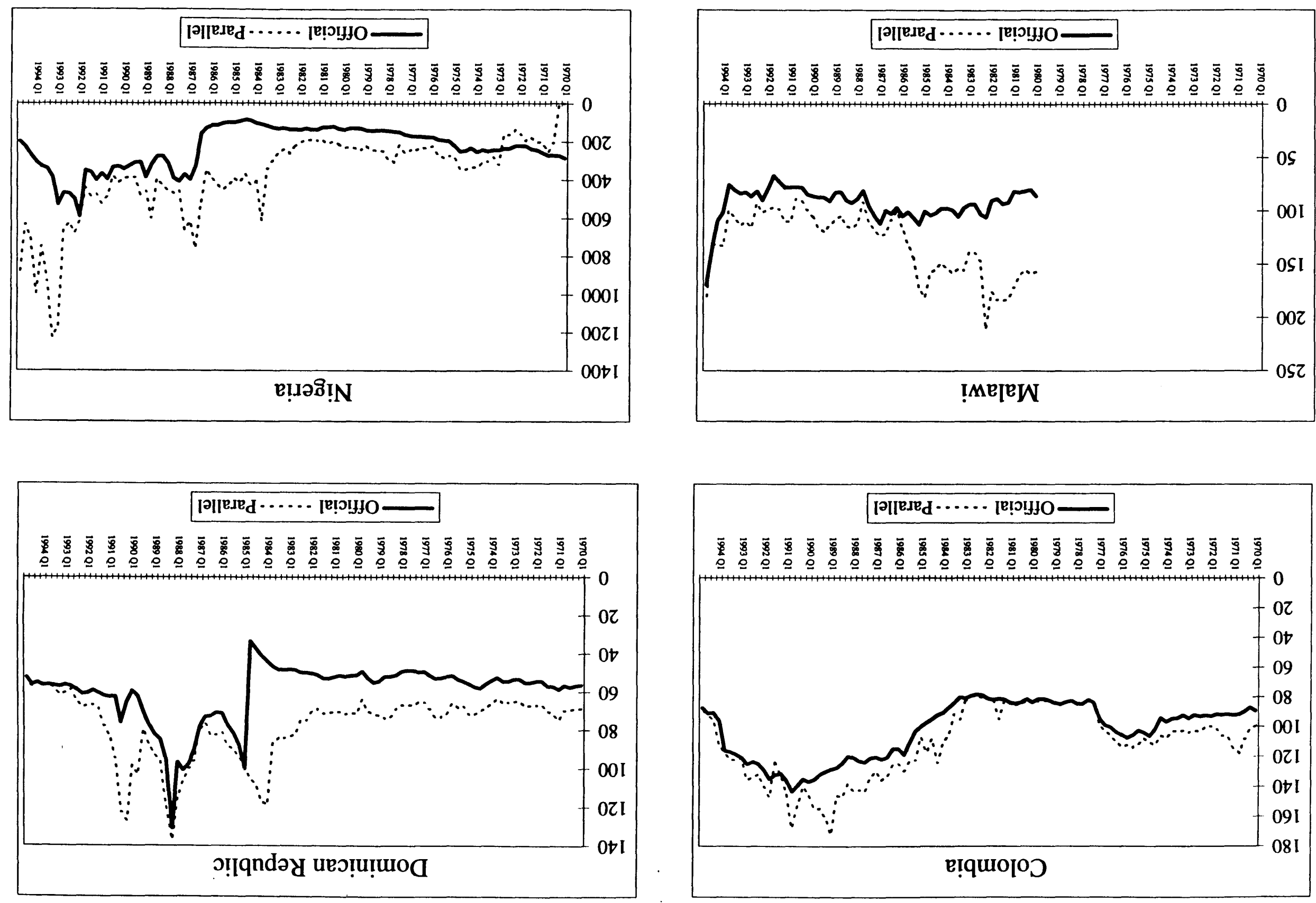

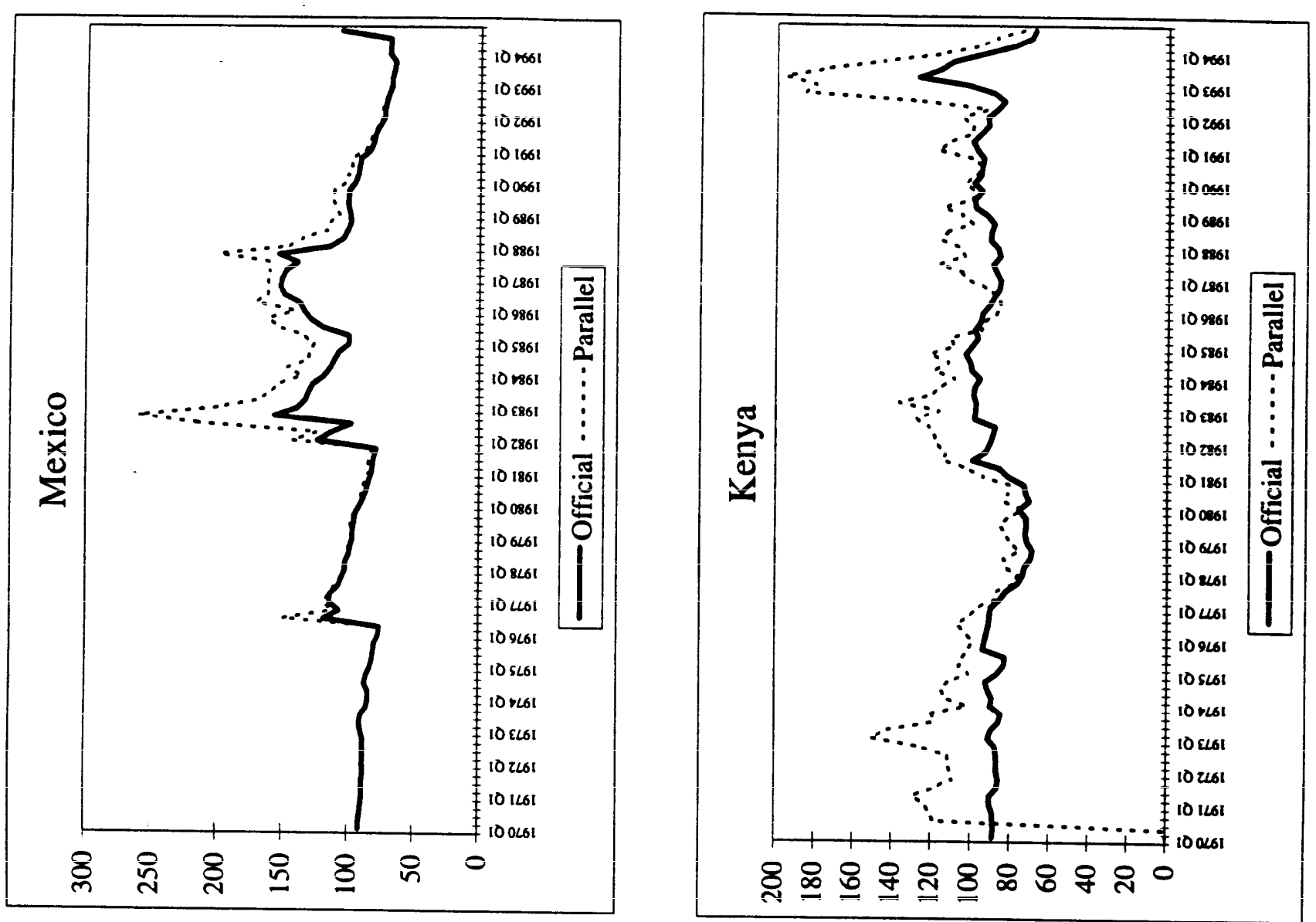

$m$
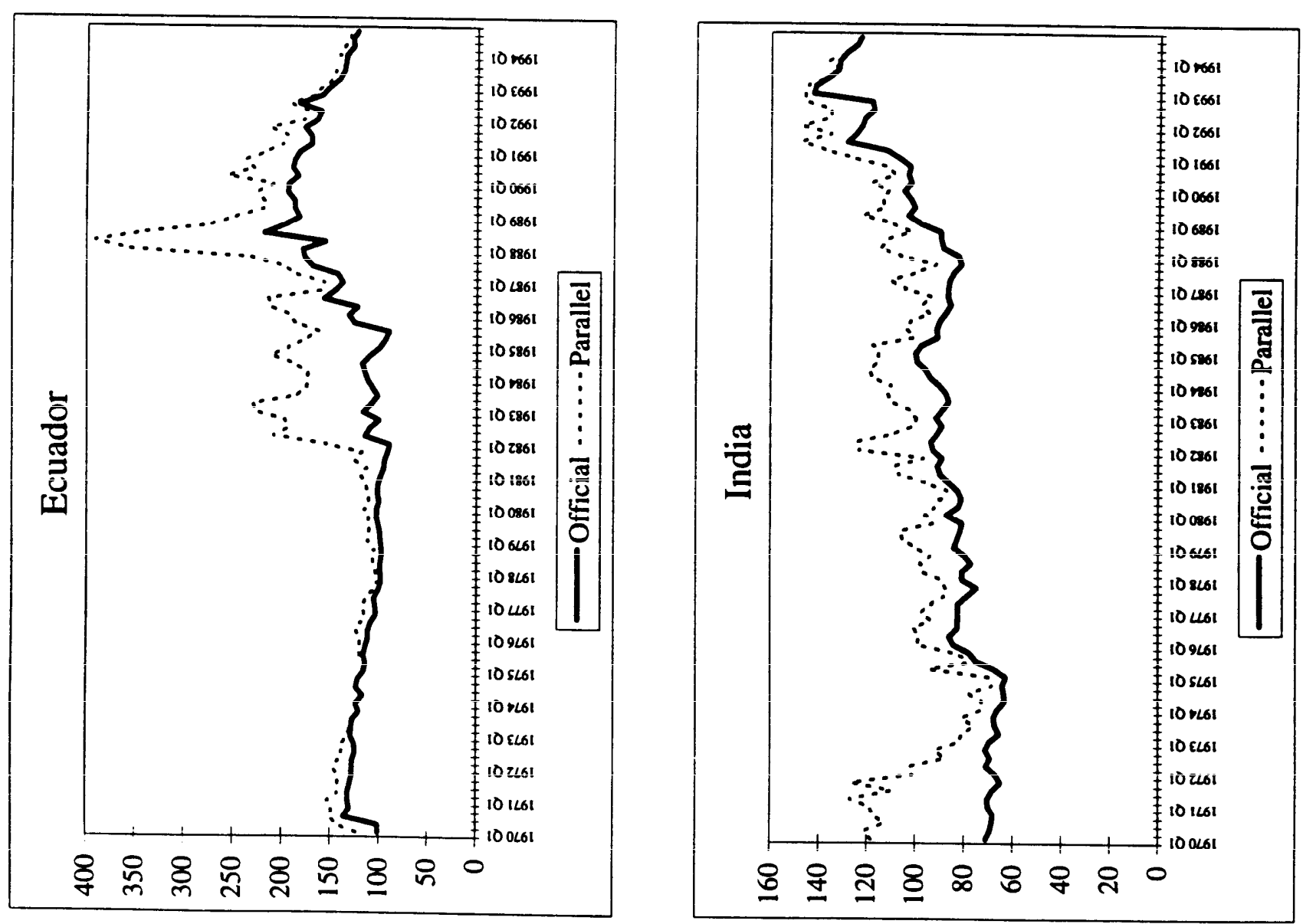

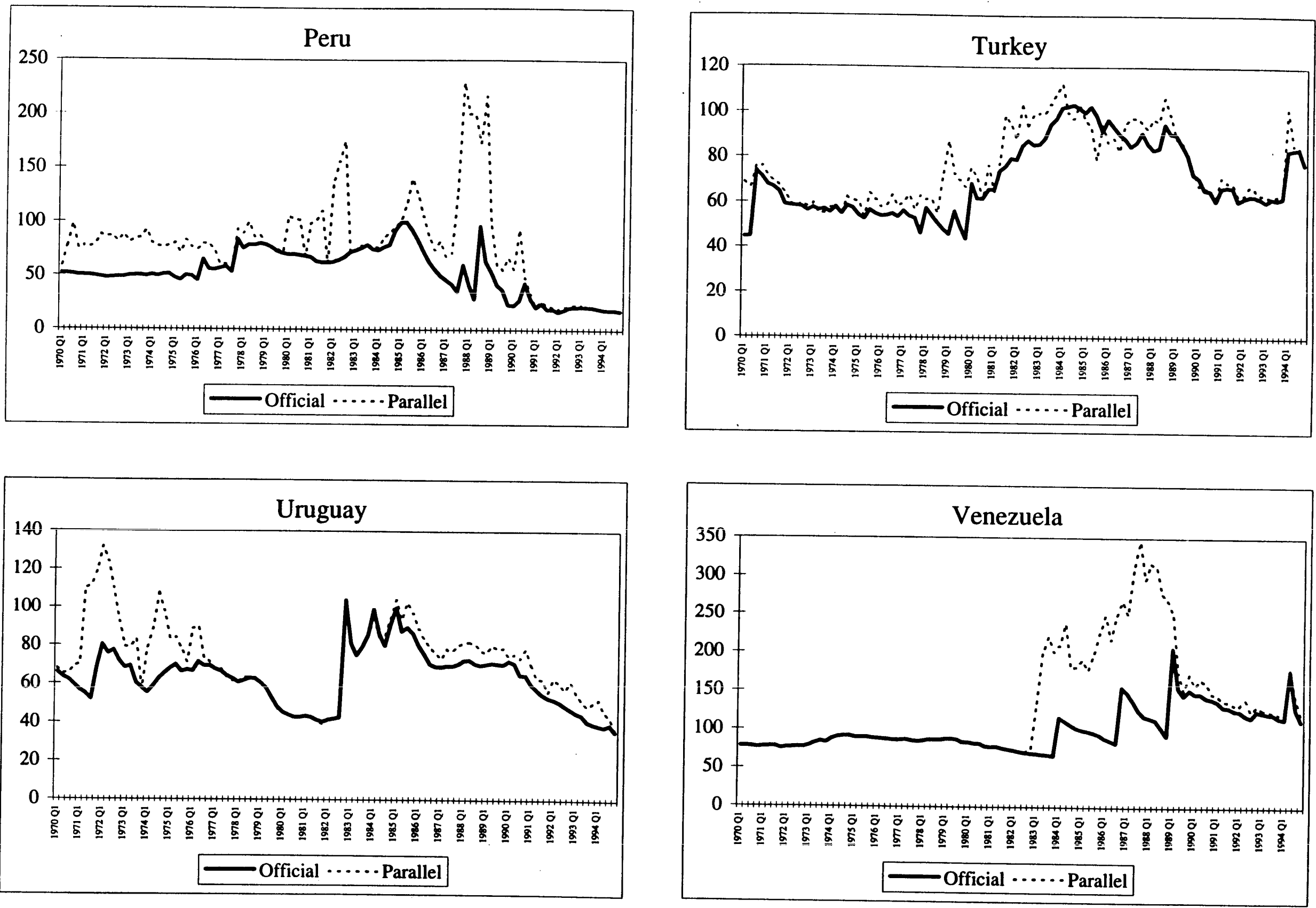

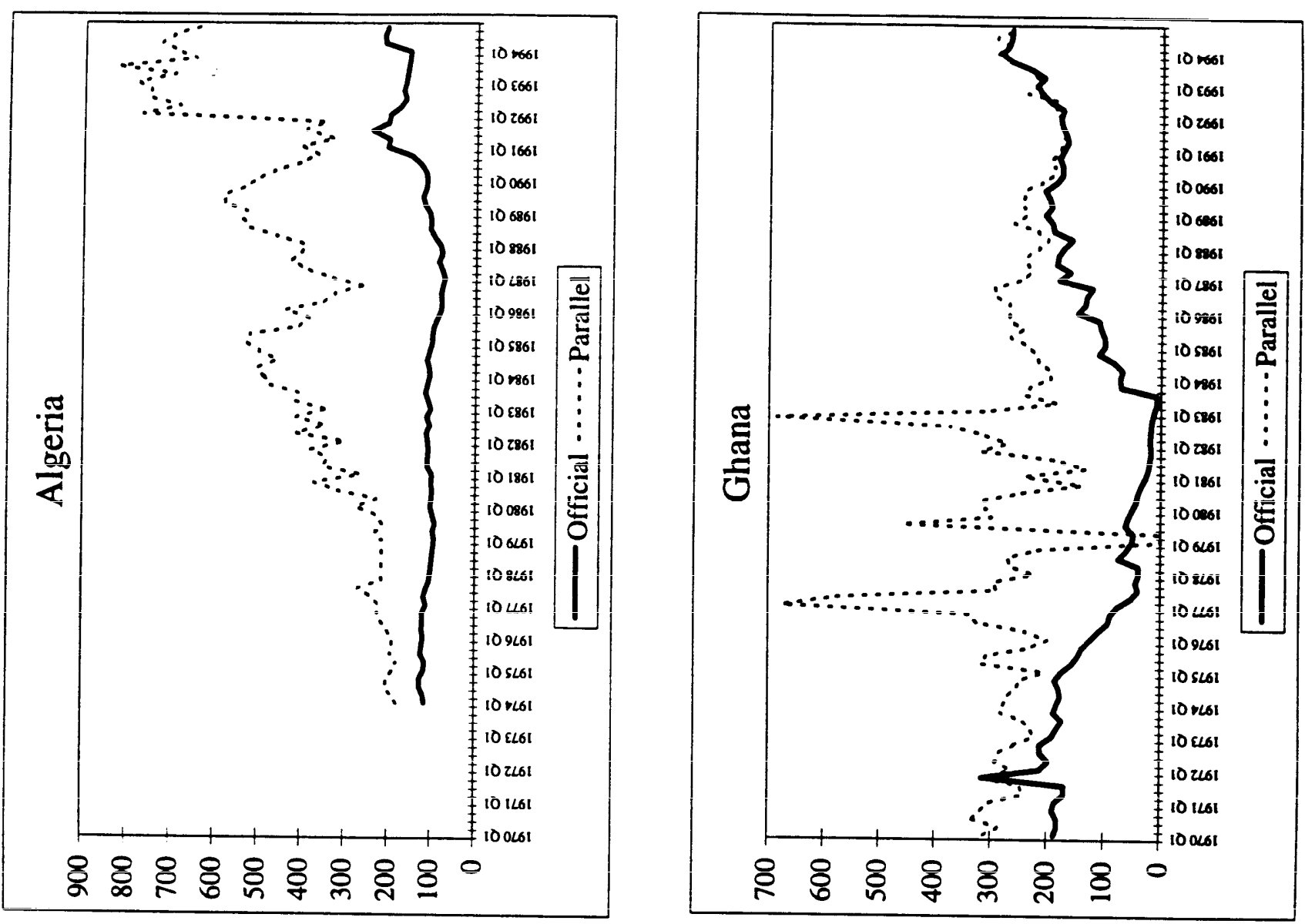

5
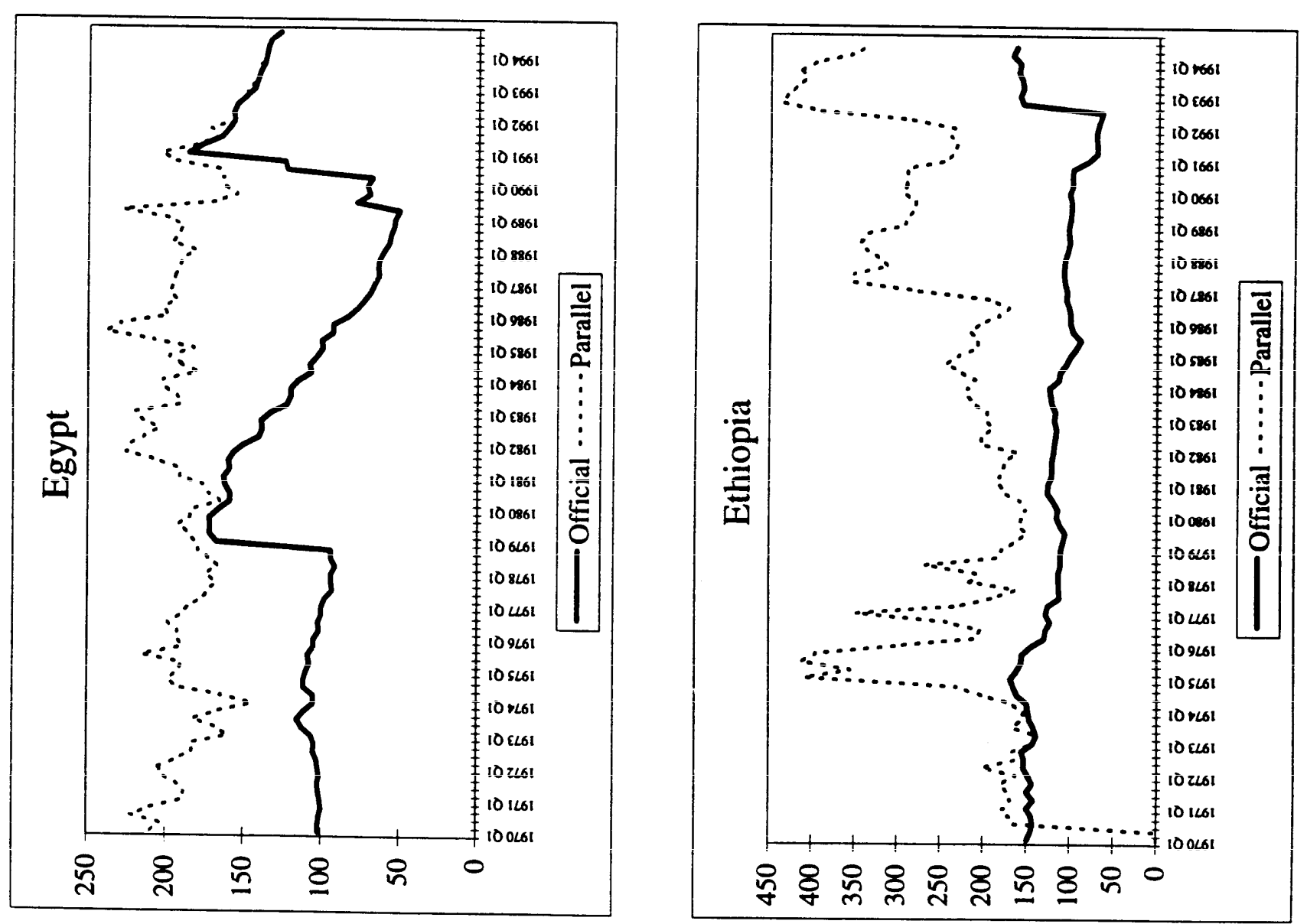

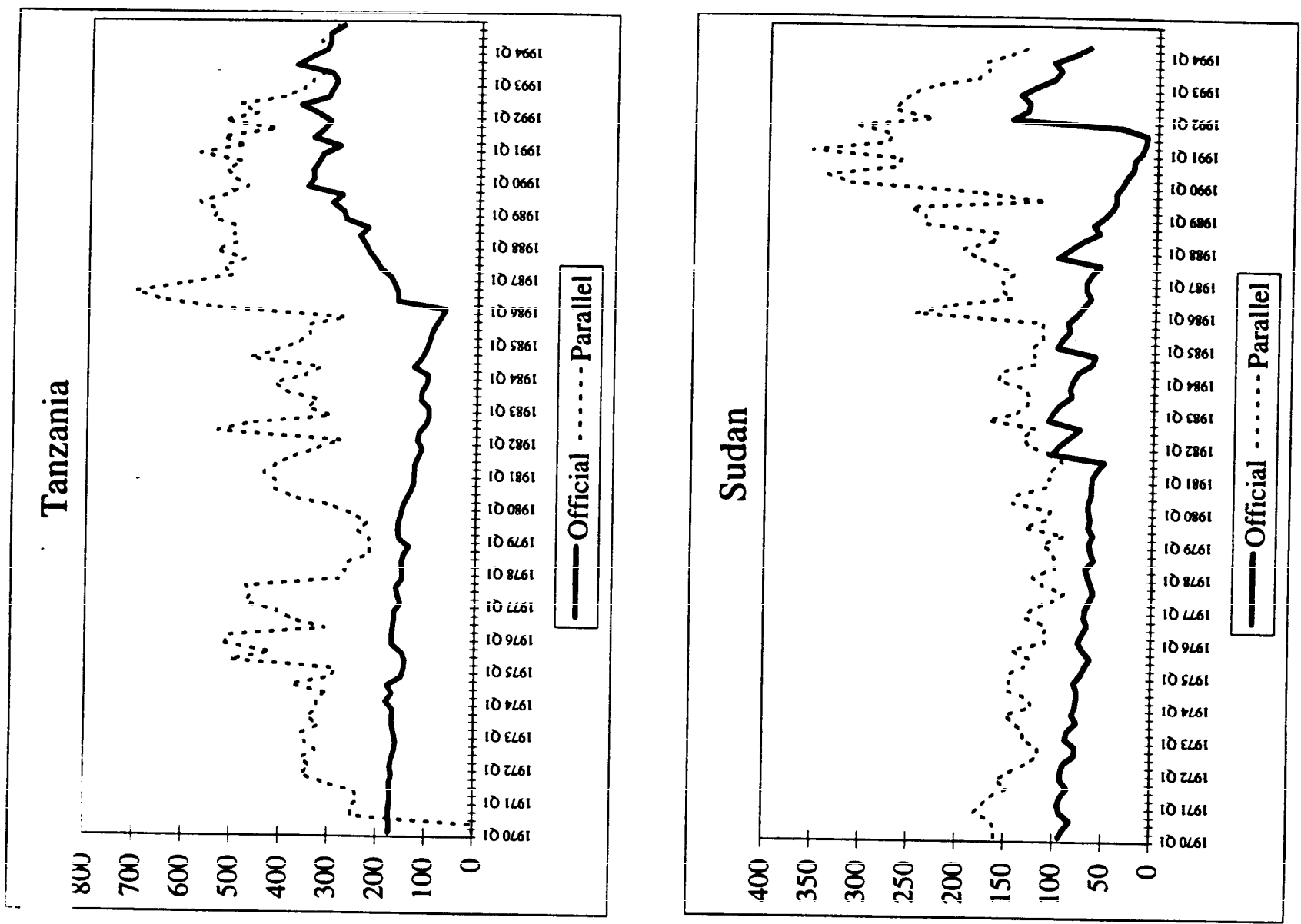

+
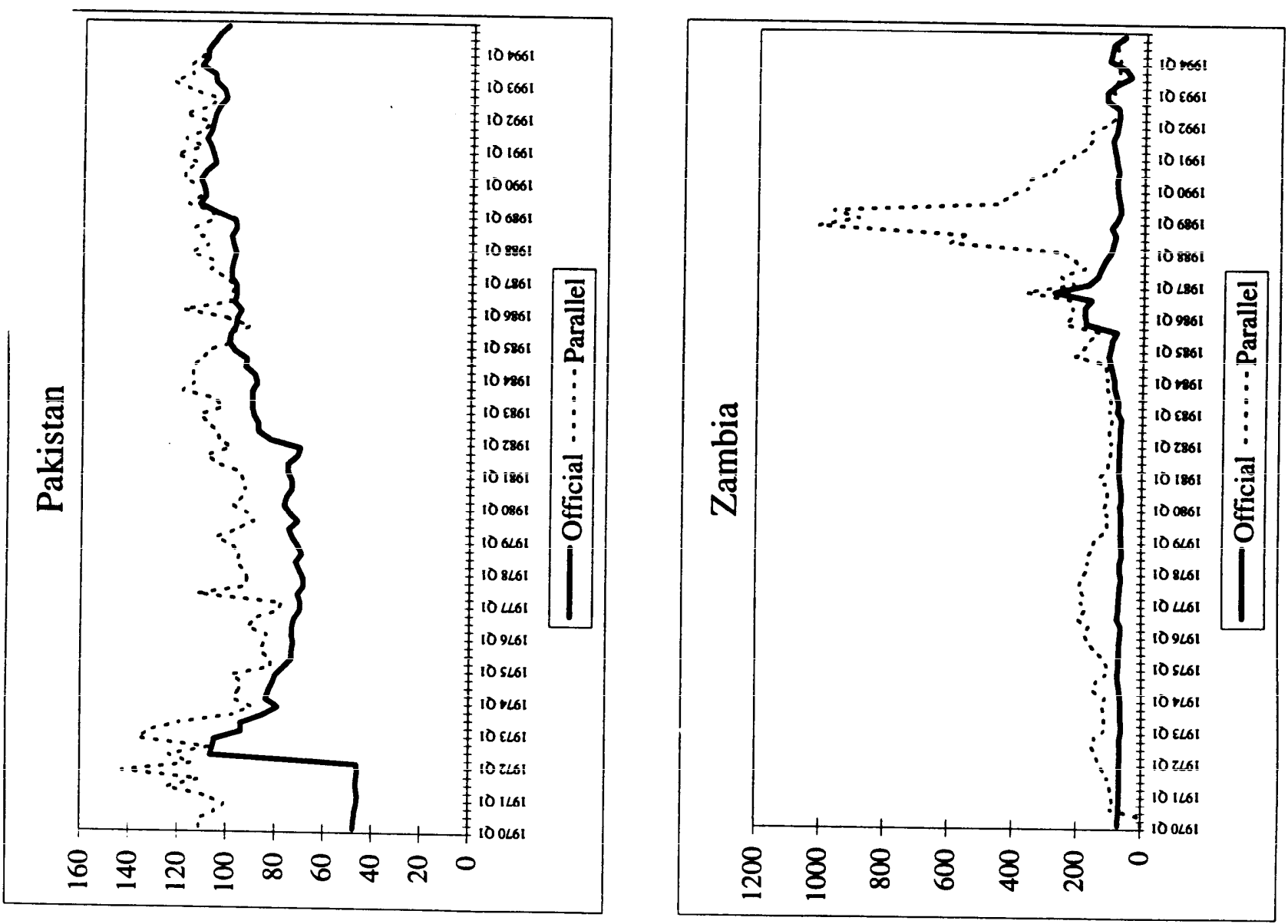


\section{International Finance Discussion Papers}

IFDP

Number

564

563

562

561

560 The Mianagement of Financial Risks at German Nonfinancial Firms: The Case of Metallgesellschaft

559 Broad Money Demand and Financial Liberalization in Greece

558 Stockholding Behavior of U.S. Households: Evidence from the 1983-89 Survey of Consumer Finances

557 Firm Size and the Impact of Profit-Margin Uncertainty on Investment: Do Financing Constraints Play a Role?

556 Regulation and the Cost of Capital in Japan: A Case Study

555 The Sovereignty Option: The Quebec Referendum and Market Views on the Canadian Dollar

554 Real Exchange Rates and Inflation in Exchange-Rate Based Stabilizations: An Empirical Examination

553 Macroeconomic State Variabiles as Determinants of Asset Price Covariances

552
The Tequila Effect: Theory and Evidence from Argentina

The Accumulation of Human Capital: Alternative Methods and Why They Matter
Nita Ghei

Steven B. Kamin

Jeffrey A. Frankel

Sergio L. Schmukler

Nathan Sheets

Simona Boata

Jane T. Haltmaier

Allen B. Frankel

David E. Palmer

Neil R. Ericsson

Sunil Sharma

Carol C. Bertaut

Vivek Ghosal

Prakash Loungani

John Ammer

Michael S. Gibson

Michaei P. Leahy

Charles P. Thomas

Steven B. Kamin

John Ammer

Martín Uribe

Murat F. Iyigun

Ann L. Owen

Please address requests for copies to International Finance Discussion Papers, Division of International Finance, Stop 24, Board of Governors of the Federal Reserve System, Washington, D.C. 20551. 


\section{International Finance Discussion Papers}

IFDP

Number
Titiles

$\underline{1996}$
550 Alternatives in Human Capital Accumulation: Implications for Economic Growth

549 More Evidence on the Link between Bank Health and Investment in Japan

$548 \quad$ The Syndrome of Exchange-Rate-Based Stabilization and the Uncertain Duration of Currency Pegs

547 German Unification: What Have We Learned from Multi-Country Models?

546 Returns to Scale in U.S. Production: Estimates and Implications

545 Mexico's Balance-of-Payments Crisis: A Chronicle of Death Foretold

$544 \quad$ The Twin Crises: The Causes of Banking and Balance-of-Payments Problems

543 High Real Interest Rates in the Aftermath of Disinffation: Is it a Lack of Credibility?

542 Precautionary Portfolio Behavior from a Life-Cycle Perspective

541 Using Options Prices to Infer PDF's for Asset Prices: An Application to Oil Prices During the Gulf Crisis

540 Monetary Policy in the End-Game to Exchange-Rate Based Stabilizations: The Case of Mexico
Comparing the Welfare Costs and the Initial Dynamics of Alternative Temporary Stabilization Policies

Long Memory in Inflation Expectations: Evidence from International Financial Markets $\underline{\text { Author(s) }}$

Murat F. Iyigun

Ann L. Owen

Michael S. Gibson

Enrique G. Mendoza

Martín Uribe

Joseph E. Gagnon

Paul R. Masson

Warwick J. McKibbin

Susanto Basu

John G. Fernald

Guillermo A. Calvo

Graciela L. Kaminsky

Carmen M. Reinhart

Graciela L. Kaminsky Leonardo Leiderman

Carol C. Bertaut

Michael Haliassos

William R. Melick

Charles P. Thomas

Steven B. Kamin

John H. Rogers

Martin Uribe

Joseph E. Gagnon 


\section{International Finance Discussion Papers}

IFDP

Number

Titles

$\underline{\text { Author(s) }}$

1996

537 Using Measures of Expectations to Identify the Effects of a Monetary Policy Shock

Allan D. Brunner

536 Regime Switching in the Dynamic Relationship between the Federal Funds Rate and Innovations in

Chan Huh

Nonborrowed Reserves

535 The Risks and Implications of External Financial Shocks: Lessons from Mexico

Edwin M. Truman

534 Currency Crashes in Emerging Markets: An Empirical Treatment

Jeffrey A. Frankel Ándrew K. Rose

533 Regional Patterns in the Law of One Price: The Roles of Geography Vs. Currencies

Charles Engel

John H. Rogers 